Georgetown University Law Center Scholarship @ GEORGETOWN LAW

\title{
Three Pictures of Contract: Duty, Power and Compound Rule
}

Gregory Klass

Georgetown University Law Center, gmk9@law.georgetown.edu

This paper can be downloaded free of charge from:

https://scholarship.law.georgetown.edu/facpub/411

83 N.Y.U. L. Rev. $1726-1783$ (2008)

This open-access article is brought to you by the Georgetown Law Library. Posted with permission of the author. Follow this and additional works at: https://scholarship.law.georgetown.edu/facpub

Part of the Contracts Commons 


\title{
GEORGETOWN LAW Faculty Publications
}

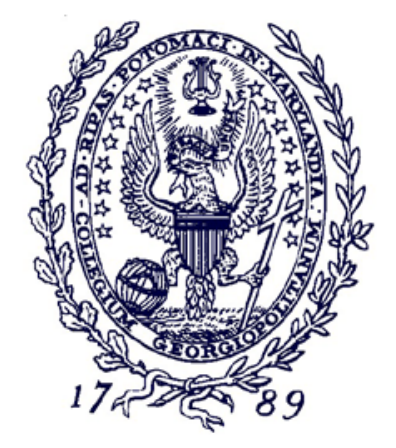

\section{Three Pictures of Contract: Duty, Power and Compound Rule}

\author{
83 N.Y.U. L. Rev. 1726-1783 (2008) \\ Gregory Klass \\ Associate Professor \\ Georgetown University Law Center \\ gmk9@law.georgetown.edu \\ This paper can be downloaded without charge from: \\ Scholarly Commons: http://scholarship.law.georgetown.edu/facpub/411/ \\ SSRN: http://ssrn.com/abstract $=1033116$
}

Posted with permission of the author 


\title{
THREE PICTURES OF CONTRACT: DUTY, POWER, AND COMPOUND RULE
}

\begin{abstract}
Gregory KLASS*
There is a fundamental divide among theories of contract law between those that picture contract as a power and those that picture it as a duty. On the powerconferring picture, contracting is a sort of legislative act in which persons determine what law will apply to their transaction. On the duty-imposing picture, contract law places duties on persons entering into agreements for consideration, whether they want them or not. Until now, very little attention has been paid to the problem of how to tell whether a given rule is power conferring or duty imposing-a question that should lie at the center of contract theory.

This Article argues that legal powers have two characteristic features. First, there is an expectation that actors will satisfy the rules with the purpose of achieving the associated legal consequences. Second, the legal rules are designed to facilitate such uses. A law might exhibit these features in either of two ways, which define two types of legal powers. Many laws that create legal powers employ conditions of legal validity, such as legal formalities, designed to guarantee the actor's legal purpose. The presence of such validity conditions is strong evidence that the law's sole function is to create a legal power, and I suggest reserving the term "power conferring" for such laws. Other laws anticipate and enable their purposive use without conditioning an act's legal consequences on the actor's legal purpose. The structure of such laws suggests that they function both to create powers and to impose duties. I coin the term "compound rule" for laws that satisfy this description and argue that the contract law we have is a compound rule. The dual function of compound rules provides empirical support for pluralist justifications of contract law. An example of such a theory can be found in Joseph Raz's comments on the relationship between contract law and voluntary obligations.
\end{abstract}

INTRODUCTION ........................................ 1727

I. How To Identify a Legal Power ................ 1734

A. The Puzzle ................................. 1735

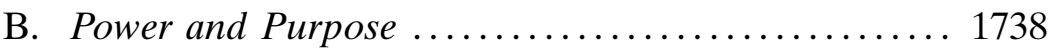

II. Power-Conferring Rules ........................ 1743

III. Compound Rules................................ 1758

IV. Contract Theory ........................... 1768

A. The Compound Picture and Pluralist Justifications .. 1769

B. A Compound Theory of Contract Law: Raz on

Contract and Promise ....................... 1773

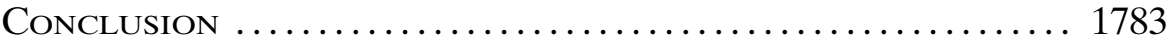

* Copyright (C) 2008 by Gregory Klass, Associate Professor, Georgetown University Law Center. This Article has benefited from comments and criticisms from Aditi Bagchi, Emma Jordan, John Mikhail, David Owens, Michael Pratt, Eyal Zamir, and Kathy Zeiler, as well as participants in the Georgetown Faculty Summer Workshop and the Georgetown Law and Philosophy Workshop, and I have benefited from the excellent research assistance of Brie Ann Carey, Conrad Deitrick, and Addison Draper. My thanks to all. 


\section{INTRODUCTION}

Theorists commonly adopt one of two pictures of contract law. On the first picture, entering into a contract is an act of self-legislation in which the parties create new legal obligations for themselves. In Lon Fuller's words: "When a court enforces a promise it is merely arming with legal sanction a rule or lex previously established by the party himself. This power of the individual to effect changes in his legal relations with others is comparable to the power of a legislature."1 On this picture, contract law is what H.L.A. Hart calls a "power-conferring" rule. It enables persons to create and modify their legal obligations to one another. The other picture depicts contract law as concerned with extralegal wrongs, such as breaking a promise, causing reliance harms, or unjustly enriching oneself at the expense of another. Consider, for example, Charles Fried's claim that "since a contract is first of all a promise, the contract must be kept because a promise must be kept."2 This suggests that the purpose of contract law is to enforce the moral obligation to perform one's promises. On this picture, contract law is what Hart calls a "dutyimposing" rule: It is designed to require promisors to perform or to compensate promisees for the harms caused when they fail to do so. ${ }^{3}$

I call these two conceptions "pictures" because, like a picture, each organizes our understanding of its subject matter. Each is a way of seeing contract law as a unified whole. And, like a picture, it is legitimate to inquire into the descriptive accuracy of each, though descriptive accuracy need not be the only criterion by which we judge them.

Many contract theorists adopt a power-conferring or dutyimposing picture not because they believe that it best describes the contract law we have, but because it follows from more general political or moral principles that justify the imposition of contractual lia-

1 Lon L. Fuller, Consideration and Form, 41 Colum. L. Rev. 799, 806-07 (1941). Fuller himself espoused a mixed theory of contract-as both conferring powers and imposing duties on the basis of reliance and unjust enrichment. See id. at 806-13 (discussing how private autonomy, reliance, and unjust enrichment can all justify imposition of contractual liability).

2 Charles Fried, Contract as Promise: A Theory of Contractual ObligaTION 17 (1981); see also id. at 132 ("The law of contracts . . is a ramifying system of moral judgments working out the entailments of a few primitive principles-primitive principles that determine the terms on which free men and women may stand apart from or combine with each other.").

3 These two competing pictures reappear in the theory of promising. See Michael Pratt, Promises and Perlocutions, in Scanlon and Contractualism 93, 93-94 (Matt Matravers ed., 2003) (distinguishing between "volitionist" and "perlocutionary" theories of promise). 
bility. ${ }^{4}$ Thus Randy Barnett's libertarian theory of legal entitlements leads him to conclude that the state is justified in enforcing promises only when the promisor manifestly intended to be legally bound in a quasi-legislative act. ${ }^{5}$ This leads naturally to a view of contract law as power conferring. By contrast, Patrick Atiyah's view that contract law ought to serve remedial principles-correcting for the harms unfulfilled promises cause and preventing the promisor's unjust enrichment-underwrites his picture of contract law as imposing tort-like duties on those who induce reliance in others. ${ }^{6}$ Similarly, Fried's commitment to the principle that "respect for others as free and rational requires taking seriously their capacity to determine their own values" explains his account of contract law as enforcing the moral obligation to perform one's promises. ${ }^{7}$

This Article approaches the question from a different direction. Rather than starting from above and asking whether one or another normative principle recommends a contract law that is power conferring or duty imposing, it starts from below and asks what picture best

4 When I speak of "contract theory" in this Article, I mean general theories of contract law as a whole. Scholarly treatments of individual doctrines or rules can also presuppose one or the other of these pictures. David Slawson, for example, suggests applying lessons from administrative law to the analysis of standard form contracts, suggesting a powerconferring picture of contract. W. David Slawson, Standard Form Contracts and Democratic Control of Lawmaking Power, 84 HARv. L. Rev. 529 (1971); see also, e.g., Stephen J. Choi \& G. Mitu Gulati, Contract as Statute, 104 Mich. L. Rev. 1129 (2006) (proposing application of principles of statutory interpretation to boilerplate). I discuss other doctrinal analyses that assume the power-conferring picture in Part III.

5 See Randy E. Barnett, A Consent Theory of Contract, 86 Colum. L. Rev. 269 (1986) [hereinafter Barnett, Consent Theory] (arguing that consent theory of contract is most plausible and coherent account of contractual obligation); Randy E. Barnett, The Sound of Silence: Default Rules and Contractual Consent, 78 VA. L. REv. 821 (1992) [hereinafter Barnett, Sound of Silence] (reconciling concept of default rules with consent theory of contract). Curtis Bridgeman has recently begun constructing an argument that Barnett's position is compatible with a corrective-justice or harm-based theory of contract law. Curtis Bridgeman, Reconciling Strict Liability with Corrective Justice in Contract Law, 75 Fordham L. Rev. 3013, 3039-40 (2007); see also Ernest J. Weinrib, Punishment and Disgorgement as Contract Remedies, 78 CHI.-Kent L. Rev. 55, 66 (2003) ("The contract effects a voluntarily assumed change in the pre-existing legal relationship between the contracting parties ...."). In several recent papers, Michael Pratt has also adopted the thesis that contract is a normative power in the Razian sense, though, so far, as an unargued assumption. Michael G. Pratt, Contract: Not Promise, 35 Fla. St. U. L. Rev. (forthcoming 2008), available at http://ssrn.com/abstract=1010229 [hereinafter Pratt, Contract: Not Promise]; Michael G. Pratt, Promises, Contracts and Voluntary Obligations, 26 LAw \& Phil. 531, 533 (2007) [hereinafter Pratt, Promises, Contracts and Voluntary Obligations].

6 E.g., P.S. Atiyah, Contracts, Promises and the Law of Obligations, 94 Law Q. Rev. 193 (1978).

7 FRIED, supra note 2, at 20. For a more recent promissory theory that "the reason contracts are enforced is because it is wrong not to keep one's word," see Stephen A. Smith, Performance, Punishment and the Nature of Contractual Obligation, 60 MoD. L. REV. 360, 367 (1997). 
describes the contract law we have. ${ }^{8}$ Such an inquiry is what Jodi Kraus calls "conceptual explanation," as distinguished from justificatory legal theory. ${ }^{9}$ The aim is "to identify a concept, or set of concepts that render the phenomena sought to be explained maximally "coherent" so as to capture the "immanent, inherent, intrinsic, or internal rationality or intelligibility, deep structure, animating or underwriting principles, logical consistency, or theoretical or conceptual unity" of contract law. ${ }^{10}$ The question is whether the dutyimposing, the power-conferring, or some other picture best captures the underlying logic of our contract law.

Answering that question requires a deeper understanding of the concepts of power-conferring and duty-imposing rules. Hart describes the distinction in The Concept of Law as follows:

Under rules of the one type, which may well be considered the basic or primary type, human beings are required to do or abstain from certain actions, whether they wish to or not. Rules of the other type are in a sense parasitic upon or secondary to the first; for they provide that human beings may by doing or saying certain things introduce new rules of the primary type, extinguish or modify old ones, or in various ways determine their incidence or control their operations. Rules of the first type impose duties; rules of the second type confer powers, public or private. Rules of the first type concern actions involving physical movement or changes; rules of the second type provide for operations which lead not merely to physical movement or change, but to the creation or variation of duties or obligations. ${ }^{11}$

This passage is representative of Hart's treatment of the power-duty distinction, which consists mainly of examples and appeals to his readers' intuitions rather than a detailed analysis of the concepts. Among other things, Hart does not discuss how to tell whether a given rule is duty imposing or power conferring. Nor have subsequent theorists examined the distinctive marks of power-conferring or duty-

8 For the purposes of this analysis, I take the contract law we have to be the collection of rules that canonical sources such as the Restatements, the Uniform Commercial Code, and the major treatises identify as the law of contract, with occasional reference to judicial application of those rules.

9 Jody S. Kraus, Legal Theory and Contract Law: Groundwork for the Reconciliation of Autonomy and Efficiency, in Legal and Political Philosophy 385, 395-410 (Enrique Villanueva ed., 2002). This mode of analysis is also distinct from what Kraus calls "causal explanatory" and "predictive" legal theory. Id. at 395-96, 400.

10 Id. at 396.

11 H.L.A. Hart, The Concept of Law 81 (2d ed. 1994). The above passage comes from Hart's introduction of the distinction between primary and secondary rules, which Hart tended to conflate with the distinction between duties and powers. Hart himself generally assumed that contract law was a private, power-conferring rule. See, e.g., id. at 27-28, 96, 250. 
imposing rules. Most theorists who discuss the power-duty distinction have a different agenda: They are concerned with structural features of law as such, rather than the best description of this or that area of law. ${ }^{12}$ And it is typically easy to tell whether a law is power conferring or duty imposing. For example, it is fairly obvious that laws against murder or theft are duty imposing, while laws assigning authority to legislatures or judges are power conferring.

It is not obvious, however, in the case of contract law. If we want to understand whether the contract law we have is duty imposing, power conferring, or something else, we need a theory of how to tell whether a law belongs to one or another of these categories. I find the beginnings of such a theory in Joseph Raz's account of powerconferring norms as rules whose function is to enable persons to effect normative change when they so desire. It follows from this definition, I argue, that a characteristic mark of a power-creating body of law is that it includes rules that anticipate and enable its purposive use. Using contract law as an example, I describe various forms such rules might take. Differentiating between them allows me to introduce a novel distinction between two types of legal powers and to thereby describe a third picture of contract law that is neither purely power conferring nor purely duty imposing.

I suggest reserving the term "power conferring" for laws designed to ensure that a person's acts result in legal change only when it is her purpose to achieve such a change. That is, power-conferring rules include conditions of validity that sort for the actor's legal purpose. The most familiar examples of such validity conditions are legal formalities. By requiring legal actors to perform an otherwise meaningless act, such as affixing a seal to an agreement, the law ensures that they expect and want the legal consequences. The presence of such validity conditions indicates that the law's sole function is to give persons the power to effect legal change.

It is possible, however, for a law to anticipate and enable its purposive use without employing such validity conditions. I coin the term "compound rule" for laws that do not condition the legal consequences of an act on evidence of the actor's legal purpose but are structured in a way that both ensures that a significant proportion of actors subject to them are likely to have such a purpose and recognizes and facilitates that purposive use. I argue that the structure of

12 See, e.g., Wesley Newcombe Hohfeld, Fundamental Legal Conceptions as Applied in Judicial Reasoning (Walter Wheeler Cook ed., 1919); Hans Kelsen, General Theory of Law and State 123-61 (Transaction Publishers 2006) (1949); Andrew Halpin, The Concept of a Legal Power, 16 Oxford J. Legal Stud. 129 (1996); H.L.A. Hart, Bentham on Legal Powers, 81 Y ALE L.J. 799 (1972). 
compound rules suggests that they function both to impose duties and to create powers.

This analysis explains why the power-duty distinction should be a site of disagreement in contract theory. It is undeniable that many contracting parties expect and want contractual liability. That is, many parties treat contract law like a legal power. The law has taken cognizance of this fact in a variety of doctrines-such as the statute of frauds, the contra proferentem rule, and the parol evidence rule-that anticipate and encourage parties' instrumental use of the law. ${ }^{13}$ Yet unlike most legal powers, the common law of contracts does not include validity conditions that clearly sort for a contractual purpose. Since the decline of the seal, parties need not adhere to a special legal form. In fact, the rules governing implied-in-fact contracts, unilateral contracts, and implied modification by postformation behavior mean that the parties need not even express their agreement in so many words. The attempt to introduce a generic intent-to-contract requirement in England has largely failed, while courts in the United States generally conform to the Restatement rule that "[n]either real nor apparent intention that a promise be legally binding is essential to the formation of a contract." 14 Taken together, these doctrinal facts make the contract law we have look more like a set of rules that imposes duties than one that confers powers. The category of compound laws provides an attractive alternative to both pictures, one that integrates insights of each without supposing that either explains all aspects of contract law.

While compound rules share characteristics of both duties and powers, they are not a simple mix of the two. Rather, they are a distinctive category of rules with a structure all their own. ${ }^{15}$ The cate-

\footnotetext{
13 See infra Part III.

14 Restatement (Second) of Contracts $\$ 21$ (1981); see also infra notes 84-91 and accompanying text.

15 There are several other connections between power-conferring rules and dutyimposing rules. First, power-conferring rules impose a duty on persons charged with enforcement to respect the exercises of the power. Second, some power-conferring rules are duty imposing in the more attenuated sense that they entail that persons ought to obey duties created by valid exercises of the power. Joseph Raz, Voluntary Obligations and Normative Powers (pt. 2), in 46 Proc. Aristotelian Soc'y 79, 89 (Supp. 1972). Third, duty-imposing rules that create private remedies are also power conferring, since "one individual [is] given by the law exclusive control, more or less extensive, over another person's duty." H.L.A. Hart, Bentham on Legal Rights, in OXFORD EsSAYS IN JURISPRUDENCE 171, 192 (A.W.B. Simpson ed., 2d ser. 1973) [hereinafter Hart, Bentham on Legal Rights]. A fourth connection can be found in Hart's suggestion that criminal excuses like mistake, accident, provocation, duress, and insanity are best understood by analogy to the role mistake, accident, and duress play as invalidating conditions in private powerconferring rules. H.L.A. HART, Legal Responsibility and Excuses, in PUNISHMENT AND Responsibility: Essays in the Philosophy of Law 28 (1968) [hereinafter Hart, Legal
} 
gory is defined by four conditions. First, because compound laws do not include conditions of validity that sort for legal purpose, we can expect that people will sometimes commit legally relevant acts-such as entering into an agreement for consideration-for reasons other than to achieve their legal consequences. Second, it must be possible to tell a story about why the law would want to attach those legal consequences to acts of that sort, a story that does not involve empowering persons to purposively effect legal change. In the case of contract law, this will be a story about why we would want to hold parties legally liable for the nonperformance of exchange agreements. Third, while the law does not sort for legal purpose, the legal consequences must be such that a significant proportion of legal actors want to bring them about. In the case of contract law, this condition is satisfied since many parties enter into contracts expecting and wanting legal enforcement. Finally, the law must include rules that anticipate and enable its purposive use. I identify a number of contract doctrines that fit this description.

The concept of compound laws is not tailored to the law of contract. It would also seem to describe, for example, marriage, which in many jurisdictions can be entered into either formally or informally. ${ }^{16}$ It is interesting that marriage and contract both involve voluntary directed obligations-what we owe others as a consequence of our chosen relationships with them. ${ }^{17}$ The significance of that fact, and whether there exist other examples of compound laws or rules, are good questions that I leave for another day.

As I have said, this Article is an exercise in conceptual explanation: The goal is to render contract law intelligible. The analysis adopts what Daniel Dennett calls the "design stance," which itself

Responsibility and Excuses]. By ensuring that criminal punishment is applied only to voluntary actions, these doctrines "maximiz[e] within the framework of coercive criminal law the efficacy of the individual's informed and considered choice in determining the future and also his power to predict that future." Id. at 46; see also id. at 49 ("[E]xcusing conditions ... provide for all individuals alike the satisfactions of a choosing system."). That is, Hart claims that criminal law has something in common with private legal powers: The criminal doctrines of mistake, coercion, and insanity permit the individual to "weigh the cost to him of obeying the law-and of sacrificing some satisfaction in order to obeyagainst obtaining that satisfaction at the cost of paying 'the penalty." $I d$. at 47.

In contrast to all of these connections, my thesis is that a law might be structured so that the very act of satisfying it could be correctly described either as the antecedent condition of a duty or as the exercise of a power, depending on the circumstances.

16 See Homer H. Clark, Jr., The Law of Domestic Relations in the United STATES $\S \S 2.1-2.4$ (2d ed. 1988) (describing laws governing formal and informal marriage).

17 For a discussion of the concept of directed obligations, see MArgaret Gilbert, A Theory of Political Obligation 35-41 (2006). For the idea of voluntary obligations, see infra notes $145-53$ and accompanying text. 
works both from above and from below. ${ }^{18}$ First, a law's function has consequences for how it must be structured. Just as an automobile's transportation function means that it must have an energy source, so the function of legal powers requires that the laws that establish them anticipate and enable their purposive use. Working from above, one can ask whether a law has those features and thereby determine whether it serves that function. Second, the design stance is also a strategy for explaining individual rules by seeking out their purpose or raison d'être. Starting from the premise that every legal rule serves some function, and taking into account general truths about the law and human nature, one can abduce a rule's likely purpose. This analysis from below is akin to determining the use of an unfamiliar tool: The structure of the artifact provides information about its intended use.

Because I begin with the law we have and ask what concepts render it intelligible, my approach is comparable to the pragmatic method that Jules Coleman employs in his theory of tort law. ${ }^{19}$ But where Coleman "seek[s] to identify the normatively significant elements of the practice and to explain them as embodiments of principle," 20 I seek to explain those elements as embodying functions. Functions occupy the space between practices and the principles that justify them. ${ }^{21}$ A principle is a broadly applicable moral or political commitment capable of justifying our legal practices; a function is a law's more immediate use or point. To say that a law serves a certain function is not yet to say what principle or principles might justify it, for a given function can be compatible with any number of principled justifications. The final Part of this Article makes a few suggestions about the implications of my functionalist account of contract law as a compound rule for the principled justification of contract law.

The Article is structured as follows. Part I describes Raz's functionalist account of legal powers and argues that the distinctive marks of power-creating laws are rules that expect and enable persons to

18 Daniel C. Dennett, True Believers: The Intentional Strategy and Why It Works, in The Intentional Stance 13, 16-17 (1987).

19 See Jules L. Coleman, The Practice of Principle: In Defence of a Pragmatist Approach to Legal Theory 3-12 (2001) [hereinafter Coleman, The Practice of Principle] (describing Coleman's pragmatic method); Jules L. Coleman, Risks AND Wrongs 6-13 (1992) (same).

20 Coleman, The Practice of Principle, supra note 19, at 5-6.

21 See Henry M. Hart, Jr. \& Albert M. Sacks, The Legal Process: Basic Problems in the Making and Application of Law 141-43 (William N. Eskridge, Jr. \& Phillip P. Frickey eds., 1994) (distinguishing between legal policies and legal principles); Joseph Raz, The Functions of Law, in The Authority of Law: Essays on Law AND Morality 163, 166-67 (1979) (distinguishing between social functions of law and legal norms). 
effect legal change purposively. Parts II and III then investigate, by way of a close examination of contract law, the different mechanisms or rules that can serve those functions. Contract law is an especially rich source for thinking about the structure of legal powers because, while it is clear that persons often treat contract as if it were a legal power, using it to purposely create legal obligations for themselves, contemporary contract law does not include rules obviously designed to sort for such a purpose. The result of this analysis is my distinction between power-conferring and compound rules, which expands our understanding of legal powers in general. Part IV draws some general conclusions for the theory of contract law. The plausibility of the compound picture of contract is evidence of the empirical strength of pluralist justificatory theories. While others have argued for pluralism from the premise that no unitary theory has yet to succeed, I show that pluralism is indicated by the very structure of contract law. Part IV also describes in some detail an example of such a pluralist theory, which I find in Raz's scattered comments on the relationship between contract and promise.

\section{I}

\section{How To Identify a Legal Power}

How can we tell whether a rule is power conferring or duty imposing? That is, how do we identify laws as one or the other? If contracting parties exercise a legal power, it is a power like that of a legislator, rather than of a judge or a police officer. By entering into a legally enforceable agreement, the parties create new duties for themselves or modify or extinguish old ones. Contract law does not, for example, generally give the parties the power to determine whether there has been a violation of a legal duty or to impose sanctions when there is one. The analysis below therefore focuses on legislative powers, though I generally omit the modifier and simply speak of "powers" or "legal powers."

To sharpen the question of how to identify a legal power, I begin with a puzzle from chapter 3 of The Concept of Law, where Hart considers and rejects attempts of sanction-centered theories to redescribe power-conferring rules as the antecedents of complex, duty-imposing rules. While Hart has a good argument against this analytic move, he never explains how to distinguish the exercise of a legal power from the formally identical satisfaction of the antecedent of a complex duty. I provide such an explanation, starting with Joseph Raz's functionalist analysis of power-conferring rules. Raz argues that the defining function of a power-conferring rule is to provide individuals with the ability to effect normative change when they so desire. A practical 
corollary of that function is that a legal power exists only when the law both anticipates and enables its instrumental use.

\section{A. The Puzzle}

In the third chapter of The Concept of Law, Hart discusses Bentham's, Austin's, and Kelsen's attempts to analyze powerconferring rules as the antecedents of larger, complex, duty-imposing laws, which are themselves conceptualized as orders backed by threat of sanctions. ${ }^{22}$ A completely stated sanction-backed duty has the form: "If and only if conditions $A, B, C, \ldots$ are satisfied, do $x$, else suffer sanction $y$." According to the expanded-antecedent argument, legal powers are not a distinct category of laws but are terms in the antecedents of conditional duties. Thus while Wills Acts appear to confer on individuals the power to determine how their assets will be distributed after death, ${ }^{23}$ they in fact specify conditions on the executor's duties in handling the estate. Their deep structure is: "If and only if there is a will duly witnessed containing such-and-such provisions, and ..., distribute the funds in accordance with such-and-such provisions, else face sanction $y$." Similarly, the U.S. Constitution's Presentation Clause ${ }^{24}$ establishes a term in the antecedent of all federal laws, which share the form: "If and only if the law has been signed by the President or passed again by a two-thirds majority of both houses, and . . . do $x$, else suffer sanction $y$." The expandedantecedent analysis is designed to answer the objection that because legal powers do not come with penalties, sanction-centered theories cannot account for them. If "[b]y greater and greater elaboration of the antecedent or if-clauses, legal rules of every type, including the rules conferring and defining the manner of exercise of private or public powers, can be restated in this conditional form," then it may well be that every law has the form of an order backed by threat. ${ }^{25}$

22 HART, supra note 11, at 35-38. I will focus on the version of the expandedantecedent argument that Hart labels as less extreme. The less extreme version recasts rules that confer powers as fragments of laws that take the form of orders backed by threats but views facially duty-imposing rules that refer primarily to private conduct, such as the rules of criminal law, as completely stated. The more extreme version recasts even the latter kind of rules as the antecedents of orders directed at officials, requiring those officials to apply sanctions for violations of the rule. Id. at 37-38; see also Hart, supra note 12, at 818-19 (describing Bentham's treatment of legal powers as fragments of larger, dutyimposing laws).

23 See generally Julian R. Kossow, Probate Law and the Uniform Probate Code: "One for the Money ...,” 61 GEO. L.J. 1357, 1394-1400 (1973) (summarizing state requirements for execution of wills); John B. Rees, Jr., American Wills Statutes (pts. 1 \& 2), 46 VA. L. REV. 613, 856 (1960) (comparing U.S. wills statutes).

24 U.S. Const. art. I, § 7, cl. 2.

25 HART, supra note 11 , at 36. 
Hart's argument against expanding the antecedent is not that it is unworkable. On the contrary, he expresses some admiration for this "formidable and interesting theory," 26 which "contains much that is illuminating." 27 But while it might be possible to translate every power-conferring rule into the antecedent condition of a dutyimposing one, the analysis achieves uniformity at the price of distortion. Expanding the antecedent obscures what is special about legal powers, which for Hart includes their connection to secondary rules and the internal point of view. In adopting this approach, "we treat as something merely subordinate, elements which are at least as characteristic of law and as valuable to society as duty." 28 This argumentwhich is the primary thrust of Hart's chapter 3 answer to the expanded-antecedent argument-rests on a promissory note. At bottom, Hart is claiming that his analysis in the book as a whole provides a richer, more powerful account of law than expanding the antecedent can. The expanded-antecedent analysis is not incoherent but impoverished.

I believe Hart makes good on this promise. But whether he does or not, his mode of argument leaves significant questions unanswered. Most importantly for my purposes, Hart never tells us how to distinguish power-conferring laws from complex, duty-imposing ones. ${ }^{29}$ This is not much of a question with respect to public power-conferring rules, which typically designate a small number of officials whose acts will identify, modify, or apply laws governing the populace as a whole. But matters are less clear when it comes to private power-conferring rules-such as the rules governing "the making of wills, contracts, [and] transfers of property" 30 — which commonly condition changes in a person's legal status on acts she herself undertakes.

The puzzle comes from the fact that many facially duty-imposing rules also include among their antecedent conditions a person's earlier voluntary acts. Raz suggests as an example the duty to pay local income taxes. ${ }^{31}$ An antecedent condition of local tax liability is resi-

\footnotetext{
26 Id. at 37.

27 Hart, supra note 12 , at 819.

28 HART, supra note 11 , at 41.

29 As Hart later observed, The Concept of Law "attempted no close analysis either of the notion of a power or of the structure of the rules by which they were conferred, save to insist that they were different from rules which imposed obligations or duties, and to reject theories such as those of Kelsen." Hart, supra note 12, at 801.

30 HART, supra note 11 , at 96.

31 Joseph Raz, Practical Reason and Norms 102 (Princeton Univ. Press 1990) (1975). Atiyah describes the same phenomenon with a different example: The courts have recently decided that a local authority which is guilty of negligence in supervising the construction of a house in accordance with the Building Regulations may be liable to an ultimate purchaser of the house. The
} 
dency, and satisfying that condition is often a matter of taxpayer choice. Local tax laws therefore give people the power to modify their legal status - to subject themselves to a new legal rule-which they can exercise by changing their residency. Many other facially duty-imposing rules exhibit the same structure. Thus the law of fraud stipulates that by holding oneself out as an expert, a speaker can undertake a duty to ensure that her statements of opinion are true. ${ }^{32}$ The United Kingdom's Official Secrets Act allows persons, by accepting employment in specified government positions, to undertake a duty not to disclose certain information else face criminal liability. ${ }^{33}$ By producing a dangerous product, a manufacturer undertakes a duty to warn. ${ }^{34}$ And California's three-strikes law gives individuals the power to change their legal status with respect to any felonies they might commit in the future by committing two or more felonies today. ${ }^{35}$

The puzzle here lies in the conditional structure of some duties: The duty applies to a person only if she first performs a voluntary act. ${ }^{36}$ The voluntary act attaches new legal consequences to the actor's subsequent behavior; by performing the act, she changes her legal status. Because the condition is voluntary, or within the actor's

liability is, of course, a liability in tort. Now that the liability is established as a matter of law, it would not seem unreasonable or odd to say that a local authority impliedly undertakes or promises to exercise due care in supervising the construction of houses. But it would have been difficult to argue for the existence of such an implied undertaking or promise prior to the establishment of legal liability. Here it is clear that the liability is first created on independent grounds, and the implication of a promise can then be read into the conduct which leads to liability.

Atiyah, supra note 6, at 205 (citations omitted).

32 See W. Page Keeton et al., Prosser and Keeton on the Law of Torts § 109, at 760-61 (W. Page Keeton ed., 5th ed. 1984) (describing generally accepted view that defendant's holding himself out, or being understood, as having special knowledge of some matter that is not available to plaintiff is implied assertion that defendant knows facts that justify his opinion, facts on which plaintiff may reasonably rely).

33 Official Secrets Act, 1989, c. 6.

34 See Restatement (Third) of Torts: Prod. Liab. § 2(d)(i) (1998) (stating that sellers of commercial products must provide reasonable warnings about risks of injury posed by products).

35 Cal. Penal Code $\S \S 667($ e)(1)-(2)(A) (West 1999); Cal. Penal Code $\S \S 1170.12$ (c)(1)-(2) (West 2004). The point here is about the structure of the law. The fact that penalties also attach to the first two crimes shows that it would be silly to interpret the three-strikes rule as a power-conferring one. But it does not destroy the structural parallel or render the interpretation impossible. Thus an anthropologist from a distant land might hypothesize that the legal consequences attaching to the first two acts might be a tax on or price for exercising the power.

36 The puzzle does not depend on the sanction theory of legal duties, according to which a duty is simply an order backed up by the threat of sanctions, which one might reject for other reasons. Thanks to David Owens for helping me to clarify this point. 
control, the duty is structurally identical to a legislative legal power. Consequently, just as any power-conferring rule can be translated into the antecedent of a legal duty, so any antecedent condition of a duty might be restated as a private power when satisfaction of the condition is under a person's control. Expanding the antecedent is a formal move that can be performed just as easily in reverse.

If this looks like an analytic sleight of hand, the result of an emphasis on form at the expense of substance, that is because it is. But the isomorphism between power-conferring rules and these complex, duty-imposing ones highlights a real question: What is the substantive difference between them? What is it that distinguishes voluntarily satisfying the antecedent of a duty-imposing rule from exercising a legal power, given that the one can always be translated into the other? The question is crucial to the theory of contract law, for contractual obligations are conditioned on the parties' earlier voluntary acts-making a promise, accepting an offer, entering into an agreement. On the power-conferring picture, that act is the exercise of a legal power; on the duty-imposing picture, it is the antecedent condition of a complex duty. Hart's thesis is that there is a difference between powers and complex duties, but he does not say what that difference is. He does not explain why the laws that he identifies as power conferring should be so classified while other, structurally identical laws should not.

\section{B. Power and Purpose}

With respect to many laws, the answer is obvious. If a law conditions a change in the actor's legal status on her commission of a wrong (such as committing two felonies), and the change in status is undesirable (a longer term of imprisonment for a third felony), it is almost certainly duty imposing. Alternatively, if a law stipulates conditions that have no extralegal meaning or purpose (consider the acts necessary to cast a vote), and attaches legal consequences to the satisfaction of those conditions that the actor is likely to desire (a vote), it is almost certainly power conferring. But such examples do not provide generally applicable criteria for marking the distinction. As the examples of local taxes, fraud liability for statements of opinion, and the Official Secrets Act show, not all duty-imposing rules condition the change in legal status on the commission of a wrong. ${ }^{37}$ And some legal powers, such as the power to marry, are exercised by acts with significant extralegal meaning as well. Contract theory is difficult because contract law exhibits none of the obvious markers of a duty

37 See supra notes 30-35 and accompanying text. 
or a power. The antecedent condition of contractual liabilityentering into an agreement for consideration-is not a wrong, distinguishing contract from complex duties like California's three-strikes law; there are many extralegal reasons one might satisfy that condition-most obviously, to engage in a value-creating exchange-distinguishing contract from most legal powers; and whether the parties want the legal consequences (enforcement of their agreement) depends on the circumstances of the transaction.

In order to get at more general criteria for distinguishing powers from duties, we need to recur to a higher level of abstraction. Joseph Raz observes that the fundamental difference between powerconferring and duty-imposing rules lies in their different functions. While the purpose of a duty-imposing law is to give persons subject to it a new reason to act in compliance with it, the purpose of a powerconferring law is to enable persons to determine, within bounds, what the law is or requires. In the latter case, the law attaches legal consequences to certain acts because "it is desirable to enable people to affect norms and their application in such a way if they desire to do so for this purpose." 38 To quote Hart again, the point of a duty-imposing rule is to require persons "to do or abstain from certain actions, whether they wish to or not," 39 while the function of a powerconferring rule is, in Raz's words, "to provide individuals with facilities for realizing their wishes." 40

If the function of a power-conferring rule is to enable persons to effect legal change purposively, it must be structured such that persons commonly satisfy the rule because they want the resulting legal change. To quote Raz again:

Only acts undertaken with the intention to legislate can be legislative acts. The reason is that the notion of legislation imports the

38 RAz, supra note 31, at 102. For an excellent overview of Raz's analysis of normative powers, see Pratt, Promises, Contracts and Voluntary Obligations, supra note 5, at 539-43.

39 HART, supra note 11 , at 81.

40 Joseph Raz, The Concept of a Legal System: An Introduction to the Theory of Legal System 158 (1970); see also Kelsen, supra note 12, at 137 ("By giving individuals the possibility of regulating their mutual relations through legal transactions, the legal order grants individuals a certain legal autonomy. It is in the law-creating function of the legal transaction that the so-called 'private autonomy' of the parties manifests itself.").

While Hart never undertook a functionalist analysis of legal powers, he endorsed Raz's approach:

Legal provisions of this kind guide those who exercise powers in ways strikingly different from the way in which rules imposing duties guide behavior: they are more like instructions how to bring about certain results than mandatory impositions of duty. Hence power-conferring rules are distinct from duty-imposing rules in their normative function . . . .

Hart, supra note 12, at 822 (citations omitted). 
idea of entrusting power over the law into the hands of a person or an institution, and this imports entrusting voluntary control over the development of the law, or an aspect of it, into the hands of the legislator. This is inconsistent with the idea of unintentional legislation. ${ }^{41}$

We expect the testator to want to determine how her property shall be distributed, that the bride and groom intend with their vows to marry, that a legislator understands the legal effect of her vote, and that a judge means the legal consequences of announcing a sentence or issuing an opinion. A power-conferring rule can serve its function only if it is designed so that legal actors who satisfy its conditions normally do so purposely, because they want the legal consequences.

By contrast, the function of duty-imposing rules-which is to give persons a new reason to act, "whether they wish to or not"-imposes no such constraint. That is, there need be no expectation that persons will satisfy the antecedent conditions of the duty for the sake of the legal consequences. While the three-strikes law gives individuals the ability to alter their legal status-by committing two felonies-we do not expect them to use the rule in that way. It would be strange to commit two crimes in order to be more severely punished for a third. Nor do we expect people to move for the sake of being taxed by the local government, to hold themselves out as experts for the sake of the increased fraud liability, or to take a government job for the sake of the special legal duties of civil servants. Hence the humor when, in Modern Times, Charlie Chaplin commits a series of minor crimes because he wants to go back to jail. ${ }^{42}$ While acts that satisfy the antecedent conditions of duties are often intentional, in the sense of being voluntary, they are not typically done for the sake of their legal consequences.

That said, acting with the right sort of legal purpose is neither a necessary nor a sufficient condition of exercising a legal power. ${ }^{43} \mathrm{~A}$ vote on the floor of the House, if it satisfies the requisite formalities, might count as a vote even though the legislator openly meant it as a joke, and one can imagine a person committing two crimes in order to get a longer sentence for the third. Legal powers qualify as such, not by virtue of the intention of legal actors, but by virtue of the structure of the legal rules that create them. Raz's more technical definition of legal powers, therefore, emphasizes not only the actor's legal purpose but the fact that the law's reason for attaching legal consequences to

41 Joseph Raz, Intention in Interpretation, in The Autonomy of LAw: Essays in Legal Positivism 249, 265-66 (Robert P. George ed., 1996).

42 Modern Times (United Artists 1936).

43 Raz makes a similar point. Raz, supra note 15 , at 81 . 
acts of that sort is its expectation that those acts will be done with the right purpose:

An action is the exercise of a legal power only if one of the law's reasons for acknowledging that it effects a legal change is that it is of a type such that it is reasonable to expect that actions of that type will, if they are recognized to have certain legal consequences, standardly be performed only if the person concerned wants to secure these legal consequences. ${ }^{44}$

On this definition, the above examples do not threaten the description of the relevant rule as creating a power or imposing a duty. That a hammer can be used to hold a door open does not make it a doorstop. Legislators do not normally undertake the actions involved in voting as a joke, and persons do not normally plan murders in order to increase the penalty for a subsequent killing. More to the point, if anomalous cases of either sort became common enough, we would expect the law to change in response, as the reason it attaches legal consequences to acts of that sort is tied to the purpose with which they are normally performed. ${ }^{45}$

This functional account of legal powers and their exercise means that power-creating laws have two characteristic features. First, the law must be designed in a way that underwrites an expectation of its purposive use-an expectation that persons will satisfy the law for the sake of the legal consequences. Second, that expectation must be the

44 Id.; see also RAz, supra note 31 , at 103.

A more complete account of this way of analyzing legal powers would address the concepts of Rechtsgeschäft and Willenserklärung in German law and legal theory. The drafters of the 1882 German Civil Code defined the exercise of a legal power in terms almost identical to Raz's:

The juristic act [Rechtsgeschäft] . . . is a private declaration of the will [Privatwillenserklärung] directed at the realization of a legal effect, an effect that follows on the authority of the legal system because it is willed. The essence of the juristic act is found in the fact that a will directed at the realization of the legal effect is confirmed, and that the legal system issues a judgment, in recognition of that will, that gives legal effect to the desired legal arrangement.

1 Motive zu dem Entwurfe eines Bürgerlichen Gesetzbuches für das Deutsche REICH, 126 (Berlin \& Leipzig, J. Guttentag 1888) (Ger.) (author's translation). For more on the concept of Rechtsgeschäft, see James R. Maxeiner, When Are Agreements Enforceable? Giving Consideration to Professor Barnett's Consent Theory of Contract, 12 Ius Gentium 92, 104-05 (2006). Thanks to Eyal Zamir for suggesting this connection.

45 I believe this answers Andrew Halpin's criticism of Raz on legal powers. Halpin, supra note 12, at 143-45. Halpin's criticisms are insufficiently attentive to the fact that Raz is proposing a functionalist definition of a type of law, whereby a law qualifies as a power if it has a certain purpose. On this view, it is not an objection that a person might exercise the power inadvertently. See id. at 144 (proposing such an objection). The possibility of an accidental exercise of the power does not show that the law's purpose is not to confer powers but only that it fulfills that purpose imperfectly. 
law's reason for attaching those legal consequences to acts of that type. To show that a law has these two features is to show that it is a legal power.

There is little doubt that contract law exhibits the first feature. Parties often enter into contracts expecting and wanting legal enforcement of their agreements. That is, many parties treat contract law as if it were a legal power. Moreover, as I argue in Part III, many rules of contract law are designed on the assumption that parties expect or want legal enforcement. Such rules embody a legal expectation that many parties mean for their contracts to be enforced.

That fact alone, however, is not enough to identify contract as a legal power. It remains to be shown that parties' purposive incurring of contractual liability figures into the law's reasons for enforcing their agreements. Such a reason is evidenced in rules designed to enable the law's instrumental use. The next two Parts identify two categories of such rules, which mark out two species of legal powers.

Before turning to that analysis, two terminological comments are in order. First, we often describe an actor's purpose by ascribing her a corresponding intent. Thus we might say that where there is a legal power, the law expects actors to exercise it with an intent to effect the associated legal change. In legal usage, however, "intent" can mean either knowledge (or belief) or purpose. ${ }^{46}$ A foreseeable death might qualify as intentional, though the killer's purposes did not include the killing. A legal expectation that most persons satisfy a law aware of the relevant legal consequences, but not for the sake of them, would not serve the defining function of legal powers. The defining feature of legal powers is not merely to ensure that persons know legal consequences of their actions but to enable them to effect the legal changes they want. ${ }^{47}$

46 See Restatement (Third) of Torts: Liab. for Physical Harm $§ 1$ (Proposed Final Draft No. 1, 2005) (distinguishing between two senses of intent: knowledge and purpose); Jack W. Meiland, The Nature of Intention 7-14 (1970) (same); Anthony Kenny, Intention and Purpose in Law, in Essays in Legal Philosophy 146, 158 (Robert S. Summers ed., Univ. of Cal. Press 1976) (1968) (same); see also Raz, supra note 41, at 283 n.16 (distinguishing between intention and knowledge in his proposed minimal intent requirement for legislative acts). Where legal liability turns on the actor's awareness of the potential legal consequences of her act, speaking in terms of belief rather than knowledge avoids the circularity of saying that an actor's legal liability depends on her knowledge of that legal liability. See Kenny, supra, at 151 n.1 (explaining that "knowledge" is used in his analysis of intentions "to include cognitive states of mind which fall short of strict knowledge").

47 This is why Hart's account of criminal excuses as "maximizing within the framework of coercive criminal law the efficacy of the individual's informed and considered choice in determining the future and also his power to predict that future" does not mean that the criminal law is a legal power. HART, Legal Responsibility and Excuses, supra note 15, at 46; see also supra note 15. 
Second, the relevant sense of "purpose" (as well as "desire," "want," "intent," and so on) is a thin one and should not be confused with the legal actor's preference, motive, or ultimate goal in acting. Thus the participants in a shotgun wedding each might prefer not to be marrying the other, but under the circumstances (for example, a shotgun pointed at them), they mean their vows to have that effect. It is their purpose to marry, though not their preference.

\section{II \\ Power-Conferring Rules}

The clearest indication that a law is concerned with the purpose with which it is satisfied is that it conditions its satisfaction on indicia of the actor's legal purpose. Validity conditions that sort for legal purpose both express a legal expectation that the law will be used instrumentally and further enable such uses. Using the rules of contract law as an example, I distinguish four types of such validity conditions: legal formalities; required nonconventional legal speech acts; legalintent tests; and nonlinguistic proxies for legal purpose. I argue both that the presence of such validity conditions indicates that the law's sole function is to create a legal power and that the evidence that contract law includes them is equivocal at best.

A legal formality is a type of act, such as the utterance of special words or the production of a document in a certain form, that has no extralegal significance. In the idiom of speech-act theory, its meaning is purely conventional, determined entirely by the legal rules that define the act's legal consequences. ${ }^{48}$ Raz observes that:

[The choice-promoting function of legal powers] explains why they are exercised either by special formal and ceremonial acts as in making a deed or getting married, or by ordinary actions whose legal consequences approximate to their non-legal and obvious consequences, as in making a contract. It also explains why most legal powers are exercised by acts with only negligible non-normative consequences, like signing, so that there are few reasons for or against doing them apart from their legal or other normative consequences. ${ }^{49}$

48 For more on the difference between conventional and nonconventional speech acts, see, for example, Kent Bach \& Robert M. Harnish, Linguistic Communication and Speech Acts 120-34 (1979), and P.F. Strawson, Intention and Convention in Speech Acts, 73 Phil. Rev. 439, 441 (1964).

49 Raz, supra note 15, at 81. Fuller described the same dynamic: "[F]orm offers a legal framework into which the party may fit his actions, or, to change the figure, it offers channels for the legally effective expression of intention." Fuller, supra note 1, at 801. "Form has an obvious relationship to the principle of private autonomy. Where men make laws 
Conditioning legal consequences on the performance of a conventional, legal speech act enables the purposive use of the law by ensuring that the actor meant to achieve those consequences. ${ }^{50}$ First, the act itself is so unusual that there is no other reason to perform it. This is why it is important that the act have "only negligible nonnormative consequences." Second, because the act is purely conventional, it can be designed to put the actor on notice of its legal effect. ${ }^{51}$ This is a function of "ceremonial acts." I will return in Part IV.B to Raz's further category of "ordinary actions whose legal consequences approximate their nonlegal" ones.

Formal conditions of validity are familiar features of public power-conferring laws. The Standing Rules of the U.S. Senate, for example, describe the oath senators must take to enter office; stipulate that at the beginning of every daily session, the question be asked, "Shall the Journal stand approved to date?"; state that every bill must receive three readings prior to passage; and require that, during a vote, the names of senators be called alphabetically and that "each Senator shall, without debate, declare his assent or dissent to the question." 52 These and other formal requirements function, inter alia, to ensure that legislation does not happen inadvertently, that legislators legislate only when it is their purpose to do so.

There was a time when at least some of what we would today call contract law included such formal validity conditions. Thus the old writ of covenant conditioned legal enforcement of certain agreements on a sealed writing. ${ }^{53}$ For the reasons described above, one would

for themselves it is desirable that they should do so under conditions guaranteeing ... the functions of form." Id. at 813-14.

50 This is not the only function of formal conditions of validity. Formalities can also be designed, for example, to provide information to third parties, to lower drafting costs, to increase certainty, to simplify subsequent inquiries into legal rights, or to put legal actors on notice of important facts. No matter what their other functions, however, formal validity conditions work to condition an act's legal effect on the actor's legal purpose.

51 See, e.g., N.Y. Gen. Oblig. Law § 5-1501(1) (McKinney 2001) (requiring that power of attorney contain cautionary language).

52 Standing Rules of the Senate, S. Doc. No. 110-9, Rule III, at 3 (2007) (requirements of oaths); id. Rule IV, at 3-4 (rules concerning Journal); id. Rule XII, at 8 (rules governing voting procedure); id. Rule $\mathrm{XIV}(2)$, at 9 (three-reading requirement).

53 See A.W.B. Simpson, A History of the Common Law of Contract: The Rise OF THE ACTION OF Assumpsit 22-25 (1987) (describing specialty requirement for writ of covenant). The writ of covenant was only one method of enforcing an agreement. A claim for a specific sum of money, for example, lay instead under the writ of debt. My use of the seal as an example is not meant to be a historical claim about its actual purposes or uses. Simpson, for example, suggests that, at least in the fifteenth century, the seal was not dispositive but purely evidentiary, and that the writ of covenant might have lain in its absence. Id. at 16-17. But see Fuller, supra note 1, at 802 (describing seal as near-perfect formality).

Another pertinent example is the Roman stipulatio, which held that some enforceable promises required a question prefaced by "Spondes-ne..." and the formal reply, 
expect the act of affixing a seal normally to be done in order to make the agreement legally enforceable. Placing an imprinted wax on the face of a written agreement, or writing on it the words "locus sigilli" or the letters "L.S.," are unusual enough acts that it is difficult to imagine them being done for any other purpose. And the ceremonial quality of the original act of affixing and impressing the wax would have put persons on notice of the act's legal consequences. ${ }^{54}$

Formal validity conditions of this sort work to ensure that the legal consequences apply if and only if it is the legal actor's purpose to achieve them. Thus the seal requirement reflects not only an expectation that parties often want contractual liability but also a requirement that they manifest such a purpose. Formal conditions of legal validity underwrite an expectation of legal purpose by sorting for it.

The fact that a law includes validity conditions of this type is strong evidence of its function. If a law's only purpose is to "entrust[ ] power over the law into the hands of a person or an institution," 55 it is not merely senseless but counterproductive to apply it to acts not done for the sake of their legal consequences. To allow a person's actions to effect a legal change she neither expects nor wants is not to grant her control over the law but to take it away-to diminish rather than enhance her autonomy. Formal validity conditions therefore enable the law's purposive use by ensuring that legal consequences attach only when that is the actor's purpose. Where a law's only function is to give persons the ability to effect legal change, we should expect it to include validity conditions that sort for legal purpose. By

"Spondeo." See W.W. Buckland, A Manual of Roman Private Law 262-65 (2d ed. 1939) (describing Roman rule). Peter Tiersma explains the stipulatio along these lines (though he maintains that the use of formality is additionally explained by Roman law's status-based conception of contractual obligations):

What the ritualistic language does, therefore, is to set this dialogue apart from the ordinary, where any words with the meaning 'promise' would suffice. This guarantees that the parties unambiguously realize that they are engaging in something special-a binding transaction. It is virtually impossible that someone could go through this ritual without intending to bind himself.

Peter Meijes Tiersma, Rites of Passage: Legal Ritual in Roman Law and Anthropological Analogues, 9 J. Legal Hist. 3, 17-18 (1988). For fascinating compendia of different types of legal ceremonies, see Bernard J. Hibbitts, "Coming to Our Senses": Communication and Legal Expression in Performance Cultures, 41 EMORy L.J. 873, 888-941 (1992), and Tiersma, supra, at 3-9.

54 A common argument for the repeal of seal requirements in the early twentieth century was that the replacement of the impressed wax with the notation "L.S." had eroded this cautionary function. See, e.g., Eric Mills Holmes, Stature and Status of Promise Under Seal as a Legal Formality, 29 Willamette L. Rev. 617, 635-37 (1993) (arguing that with "relaxation of form, the significance of the seal has substantially declined," to point at which it can no longer fulfill function of legal formality).

55 See supra text accompanying note 41. 
the same token, the presence of conditions of legal validity that sort for legal purpose indicates that this is the law's sole function. I suggest reserving the term "power conferring" for laws of this general type-laws whose sole function is to give persons the power to effect legal change. The distinguishing marks of power-conferring laws are validity conditions that sort for legal purpose.

Laws that include formal conditions of validity are the most obvious, but hardly the only, example of power-conferring laws so defined. Rather than conditioning satisfaction of the rule on compliance with a legal convention, a law might condition it on performing a speech act with the right meaning, regardless of whether that meaning is expressed in a conventional form. This is the rule governing the validity of deeds, which demands only that the document purport to perform the relevant legal act, not that it comply with a special form.

An effective deed must, of course, contain operative words of conveyance, words which indicate the grantor's intention to convey his property; but the absence either in deeds or in wills of technical operative words will not usually be regarded as adequate cause for defeating an intention which is found upon examination of the whole instrument to be plainly though untechnically expressed. ${ }^{56}$

Or consider an example from the U.S. law of presidential powers. The Department of Justice's Office of Legal Counsel (OLC) has concluded that the effect of an executive order depends not on its form but on the content of what is said:

[There is] no basis for drawing a distinction as to the legal effectiveness of a presidential action based on the form or caption of the written document through which that action is conveyed. .. . [I]t is

56 Waller v. Brown, 149 S.E. 687, 688 (N.C. 1929); see also, e.g., Horton v. Murden, 43 S.E. 786, 787 (Ga. 1903) ("There must always appear on the face of the instrument enough to indicate an intention to convey an interest in the property described. But while proper words are necessary, 'grant,' 'bargain,' 'sell,' and other technical expressions need not be used."); Shadden v. Zimmerlee, 81 N.E.2d 477, 479 (Ill. 1948) ("No particular form of words is necessary, but it must appear from the language employed that it was the intention to convey the title and the language must purport to have that effect."); Lim v. Choi, 501 S.E.2d 141, 143-44 (Va. 1998) ("A writing need not be in any particular form to constitute a deed. Nonetheless, a document purporting to convey title must contain operative words manifesting an intent to transfer the property.").

While courts often equate the use of words that purport to perform the legal act (which are translatable into a sentence of the form "I hereby ...") with the expression of an intention to perform the act in question, these are speech acts with different meanings. See Pope v. Burgess, 53 S.E.2d 159, 160-61 (N.C. 1949) ("The language used in the instrument under review, while sufficiently pointed as to the description of the property, and while the instrument itself is referred to as a conveyance, does no more than to state the intention of the parties respectively that the survivor should have the property described without using any words or language which might, under the most liberal construction by the Court, be regarded as transferring a present interest."); see also infra note 82. 
the substance of a presidential determination or directive that is controlling and not whether the document is styled in a particular manner. ${ }^{57}$

Translated into the idiom of speech-act theory, the OLC's position is that the President need only perform a legal speech act with the meaning "I hereby invoke my executive power to order ..." without regard to whether the statement is in a conventional form or contains magic words. ${ }^{58}$

Because people generally mean what they say, conditioning legal effect on the performance of a legal speech act, whether conventional or not, works to ensure that legal actors mean the legal consequences of their acts. ${ }^{59}$ Laws whose conditions of validity include the commission of a legal speech act therefore qualify as power-conferring rules in my technical sense.

Contract law could have adopted a similar rule. In an alternate universe, the seal might have been replaced with a requirement that the parties perform any speech act with the meaning "We hereby contract to ...."60 This would have marked out contract law as a powerconferring rule in the sense I have defined. This is not, however, the contract law we have. Unlike the laws governing deeds and executive orders, contemporary contract law does not condition the existence of a contract on the performance of a legal speech act. With the demise

57 Legal Effectiveness of a Presidential Directive, as Compared to an Executive Order, Op. Off. Legal Counsel (Jan. 29, 2000), http://www.usdoj.gov/olc/predirective.htm.

58 Presumably, it is necessary that this be the literal and direct meaning of the act and not, for example, a metaphorical or whimperative one. See BACH \& HARnish, supra note 48, at 60-76 (outlining characteristics of literal versus nonliteral illocutionary acts within speech act schema).

59 In the idiom of speech-act theory, illocutionary intent-the intent to perform a speech act with a certain meaning — is strongly correlated with perlocutionary intent - the intent to achieve a certain result. See Peter Meijes Tiersma, The Language of Offer and Acceptance: Speech Acts and the Question of Intent, 74 CAL. L. REv. 189, 226-29 (1986) (describing relationship between illocutionary intent to perform speech act of offering and various perlocutionary intentions, such as intent to create certain impression in offeree or intent to perform act in question). A more detailed account of the connection between nonconventional legal speech acts and the speaker's legal purpose would involve a tour through late-twentieth-century speech-act theory. Important sources here would include Bach \& Harnish, supra note 48, at 12-18, John R. Searle, Speech Acts: An Essay in the Philosophy of Language 42-50, 54-71 (1969), H.P. Grice, Meaning, 66 Phil. Rev. 377 (1957), reprinted in Paul Grice, Studies in the Way of Words 213 (1989), and Strawson, supra note 48.

60 This is how Peter Tiersma analyzes the speech acts of offer and acceptance. Tiersma, supra note 59, at 198-206; see also Tiersma, supra note 53, at 18-19 (suggesting that ritualistic language in contract law has been supplanted by equivalent nonritualistic expressions). While Tiersma's careful analysis nicely captures what a perlocutionary act of contracting looks like, he does not have an argument that the law requires such an act for the formation of a contract. 
of the seal, all that is necessary is that party $A$ commit herself to $x$ in exchange for party $B$ 's commitment to $y$ or actual $y$ ing. That is, an agreement for consideration, sometimes in writing, is enough. Entering into an agreement is not in itself a legal speech act, in the way that executing a deed or issuing an executive order is.

In fact, contemporary contract law does not even require that the parties express their agreement in so many words. ${ }^{61}$ To take a textbook example, a request for a physician's services ("Would you please take care of my daughter?") is considered an implied-in-fact offer to pay for those services, though there is no mention of the exchange or of a return promise, much less an implicit reference to legal enforcement. ${ }^{62}$ Similarly, it has long been recognized that an offer can invite acceptance by performance-by doing the act requested, rather than expressly promising or agreeing to do it-and that, in some instances, such performance binds the offeree to the unilateral contract as if she had accepted in words. ${ }^{63}$ In cases in which the parties' written or oral communications neither agree on terms nor express assent to the same transaction, both the Uniform Commercial Code and the Second Restatement allow that "appropriate conduct," such as the shipment and acceptance of goods, "may be sufficient to establish an agreement." 64 Even the character of postformation performance can effectively modify the parties' legal obligations. Thus the parties' course of performance can "supplement or qualify" 65 their agreement and can be used "to show a waiver or modification of any term incon-

61 See Barbara Fried, Is as Ought: The Case of Contracts, 92 VA. L. REv. 1375, 1379 (2006) (noting absence of promissory acts in formation of many contractually binding agreements); Robert Samek, Performative Utterances and the Concept of Contract, 43 Australasian J. Phil. 196, 203-07 (1965) (distinguishing between promises and various senses of "agreement"). Karl Llewellyn was the most influential proponent of this view of contract formation. See U.C.C. § 1-201(3) (1951) (“'Agreed' or 'Agreement' means the bargain in fact as found in the language of the parties or in course of dealing or usage of trade or course of performance or by implication from other circumstances."); id. $\S 2-204(2)$ ("Conduct by both parties which recognizes the existence of a contract is sufficient to establish a contract for sale even though the moment of its making cannot be determined."); K.N. Llewellyn, Our Case-Law of Contract: Offer and Acceptance, II (pt. 3), 48 YALE L.J. 779 (1939) (discussing his theory of business contracts).

62 See, e.g., Benton v. Stadler, 234 N.W. 739, 740 (Wis. 1931) (holding father liable for medical services performed on his daughter at his request).

63 Restatement (Second) of Contracts $\$ 62$ (1981).

64 U.C.C. § 2-204, Purposes of Changes (2004); see id. § 2-204(1) (“A contract for sale of goods may be made in any manner sufficient to show agreement . . .."); id. § 2-207(3) ("Conduct by both parties which recognizes the existence of a contract is sufficient to establish a contract for sale although the writings of the parties do not otherwise establish a contract.”); Restatement (SECOND) OF CONTRACTs $§ 19$ (1981) ("The manifestation of assent may be made wholly or partly by written or spoken words or by other acts or by failure to act.").

65 U.C.C. $\$ 1-205(3)$ (2004). 
sistent with such course of performance." 66 Not only does the law no longer require a legal speech act with the meaning "I hereby contract to ....", it does not require that the agreement be expressed in a speech act at all. ${ }^{67}$

It is difficult to imagine a public legislative power of this sort. Public officials exercise their power to change the law or to modify an individual's legal status by performing legal speech acts of the right sort, be they formal or informal. In fact, Raz suggests this is a defining feature of legislative acts in general:

$A$, being an agent who has legal authority to make a law that $p$, legislates (i.e. makes it the law) that $p$ (where $p$ is a variable for the statement of the content of the law) by performing an action which expresses the intention that $p$ become the law in virtue of that intention being manifestly expressed. ${ }^{68}$

Most private legal powers also require a legal speech act for their exercise. A power of attorney must be in a certain form, a will must

66 Id. $\S 2-208(3)$. For a more detailed description of these aspects of the Uniform Commercial Code, including the difficulty in contracting around them, see Lisa Bernstein, Merchant Law in a Merchant Court: Rethinking the Code's Search for Immanent Business Norms, 144 U. PA. L. Rev. 1765, 1782-87 (1996).

67 One way of putting this point is that not every agreement, and therefore not every contract, involves a promise, where "promise" means an explicit undertaking of an obligation. I discuss this idea further in Part IV.B, where I describe the differences between promises and Raz's concept of voluntary obligations. See infra notes 147-51 and accompanying text. Both Michael Pratt and Aditi Bagchi have recently argued that not all contracts are promises, but for a very different reason. Pratt, Contract: Not Promise, supra note 5; Aditi Bagchi, Contract v. Promise (Univ. of Pa. Law Sch., Pub. Law \& Legal Theory Research Paper Series, Paper No. 07-35, 2007), available at http://ssrn.com/ abstract $=1012150$. Pratt and Bagchi both observe that it is possible to exercise the legal power to contract without at the same time incurring a moral obligation to perform. While I agree that some contracts do not come with promissory or other extralegal obligations to perform, my point here is that one can also incur a moral obligation to perform, to which a legal obligation attaches, without making a promise. For a different argument that contract law enforces nonpromissory extralegal obligations, see generally Anne De Moor, Are Contracts Promises?, in Oxford Essays in Jurisprudence 103 (John Eekelaar \& John Bell eds., 3d ser. 1987).

68 Raz, supra note 41, at 266. Hart adopts a similar position when describing Bentham on legal powers: "In entering into such legal transactions [a person] does an act (usually the writing or saying of certain words according to more or less strictly prescribed forms) which manifest certain intentions as to future rights and duties of himself and others." Hart, Bentham on Legal Rights, supra note 15, at 179.

Both Hart's and Raz's descriptions of legislative acts are influenced by Austin and Strawson's work on performatives. See Hart, supra note 12, at 820 (discussing relevance of speech-act theory to analysis of legal powers). One might argue that, as a historical matter, the analysis of legal powers has been impeded by speech-act theory, which has concentrated attention on the way that special speech acts figure into the exercise of legal powers at the expense of other ways in which they can be exercised. 
be signed and witnessed, a deed requires operative language. ${ }^{69}$ Contract is different: It requires only an agreement for consideration.

It does not follow, however, that contract law is not a powerconferring rule. Power-conferring laws are characterized by conditions of validity that sort for legal purpose. While requiring a legal speech act, formal or informal, is the most common mechanism ensuring a legal purpose, it is not the only one available.

Let me begin with a somewhat artificial example: the black-letter rule in England that "[a]n agreement, though supported by consideration, is not binding as a contract if it was made without any intention of creating legal relations." 70 According to this rule, among the conditions of contractual validity is the parties' initial intent to be legally bound. Courts have interpreted this test as an objective one. Legal liability depends not on the parties' actual, perhaps secret, intent but on their manifest intent - the intent that a reasonable person in each party's epistemic situation would attribute to the other. ${ }^{71}$ The rule instructs courts to consider all of the available evidence, including what the parties said, the nature of the agreement, and other contextual factors. ${ }^{72}$ Finally, it appears from the cases that anticipating legal

69 See, e.g., N.Y. Gen. Oblig. Law § 5-1501 (McKinney 2001) (stipulating form to be used to create power of attorney); N.Y. Est. Powers \& Trusts LAw § 3-2.1 (McKinney 1998) (specifying formal requirements to execute will); see also supra note 56 (detailing case law on requirements to create deed).

70 Guenter Treitel, The Law of Contract 149 (10th ed. 1999); see also M.P. Furmston, Cheshire, Fifoot and Furmston's Law of Contract 121-31 (14th ed. 2001) (discussing circumstances in which contract is denied on ground that there is no intention to create legal liability). The leading English case for the principle is Balfour $v$. Balfour, [1919] 2 K.B. 571.

It bears mentioning that most civil law countries have something like the English rule on their books. Thus the Commission on European Contract Law's Principles of European Contract Law state: "In order to be bound by a contract a party must have an intention to be legally bound. Whether in fact it has such intention is immaterial if the other party has reason to infer from the first party's statement or other conduct that it intends to be bound ...." Principles of European Contract Law art. 2:101 cmt. B (Comm. on European Contract Law, Ole Lando \& Hugh Beale eds., 2000). See generally id. arts. 2:101-:102 and accompanying notes (discussing European sources of law). While the practical effect of such rules would be an interesting avenue for further research, I hesitate to draw quick conclusions about such different legal traditions. The French Civil Code, for example, states that "[a]greements lawfully entered into take the place of the law for those who have made them." CODE CIVIL art. 1134 (Fr.). While this might look something like the powerconferring picture of contract law, James Gordley argues that the provision in fact reflects the influence of the natural law tradition on the French Civil Code. JAmEs Gordley, The Philosophical Origins of Modern Contract Doctrine 217-19 (1991). If he is correct, "law" in article 1134 is better understood as referring to the moral law that contract law enforces.

71 Treitel, supra note 70 , at 158.

72 See id. at 151-59 (describing contextual factors and evidentiary presumptions affecting likelihood of court finding intent to be legally bound). 
liability is enough to satisfy the intent requirement. ${ }^{73}$ That is, "intent" here stands for belief, not purpose; the English rule does not require that the parties want legal enforcement but only that they expect it.

While the English rule does not condition contractual liability on the parties' contractual purpose, an objective intent to contract is strongly correlated with such purpose. First, objective intent (the intent that is reasonable in the circumstances to attribute to a person) is good evidence of subjective intent. And because the conditions of contractual validity must be both observable and verifiable, objective intent might be, all things considered, the best proxy for subjective intent. ${ }^{74}$ Second, while the English rule appears to be satisfied by a mere belief about legal consequences, practical beliefs of this sort are strongly correlated with an agent's purpose. At least in theory, the law gives parties who do not want contractual liability a cheap and easy way to avoid it—by including a TINALEA clause ("This is not a legally enforceable agreement.") or otherwise manifesting that preference. ${ }^{75}$ If the parties anticipate legal liability and have not exercised their option to avoid it, the most likely explanation is that they want to enter into a contract.

In short, if the English rule works as advertised, it appears to sort for contractual purpose. By conditioning enforcement on the parties' manifest beliefs as to the legal consequences of their agreement, the English rule supports the expectation that, in the normal case, a contract exists only when the parties want legal liability. And the rule does so without requiring courts to ask whether the parties engaged in a legal speech act of one type or another. It is enough if the totality of the circumstances-the words used, the type of agreement, the parties' background understandings, their behavior under the agreement, and other extrinsic evidence-demonstrates a contractual intent. The English rule indicates how a law might be power conferring without requiring a legal speech act for the exercise of the power.

73 I know of no opinion directly addressing whether "intent" in the English rule refers to belief or purpose. But in Ford Motor Co. v. Amalgamated Union of Engineering Foundry Workers, the court based its finding-that the parties to a collective bargaining agreement did not intend to be bound-solely on evidence of their reasonable expectations, given the state of the law and legal scholarship on the question. [1969] 2 Q.B. 303.

74 See Barnett, Consent Theory, supra note 5, at 300-09 (arguing that, since it is based on notions of entitlements, consent theory of contract looks to objective rather than subjective manifestations of intent); Barnett, Sound of Silence, supra note 5, at 855-59 (discussing problems with relying on subjective intent and resulting need to rely on objective appearances).

75 Treitel, supra note 70 , at 150. 
But there are reasons to doubt that the English rule works as advertised. ${ }^{76}$ Absent a legal speech act or express statement of intent, evidence of the parties' objective intent with respect to contractual liability is often absent or equivocal at best. ${ }^{77}$ When interpreting commercial agreements, English courts have therefore adopted a strong presumption that where the other elements of contractual liability are present, the parties intended legal liability. ${ }^{78}$ As a result, the English rule is most often invoked in situations in which, for one reason or another, there is a judicial intuition that legal liability is inappropriate. Examples include agreements between spouses, collective bargaining agreements, and ecclesiastical employment agreements. ${ }^{79}$ Hence the common criticism that the rule serves as a cover for policy judgments about the appropriate limits of contract law, rather than as a means of ensuring the parties' contractual intent. ${ }^{80}$ While the English rule represents contract law to be a power-conferring rule, judicial application of the rule suggests that we should not take this self-representation too seriously.

This is not to say that it is impossible to condition legal enforcement on proof of the parties' contractual intent. The problem with the English rule is an evidentiary one, and it might be solved with different evidentiary rules. The Model Written Obligations Act, for example, would condition the enforcement of promises without consideration on an express statement of intent: "A written release or

76 See Stephen Hedley, Keeping Contract in Its Place-Balfour v Balfour and the Enforceability of Informal Agreements, 5 Oxford J. Legal STud. 391, 393-97 (1985) (critically discussing judicial experience with English rule). Atiyah concludes that it is "more realistic to say that no positive intention to enter into legal relations needs to be shown, and that 'a deliberate promise seriously made is enforced irrespective of the promisor's views regarding his legal liability.'” P.S. Atiyah, An Introduction to the Law of Contract 153 (5th ed. 1995) (quoting 1 Samuel Williston, A Treatise on the Law of Contracts 39 (3d ed. 1957)).

77 Hedley, supra note 76, at 394-95.

78 See AтіYAн, supra note 76, at 154-55 (describing presumption that business or commercial dealings are intended to have legal effect); TREITEL, supra note 70 , at 157-58 (describing presumption in favor of finding contract where claim is based on proved or admitted express agreement).

79 See President of the Methodist Conference v. Parfitt, [1984] 1 Q.B. 368 (holding that clerical employment agreements are not contracts); Ford Motor Co. v. Amalgamated Union of Eng'g Foundry Workers, [1969] 2 Q.B. 303 (holding that collective bargaining agreement did not give rise to contractual liability); Balfour v. Balfour, [1919] 2 K.B. 571 (holding that agreement between spouses was not contract); see also Cohen v. Cowles Media Co., 457 N.W.2d 199, 203 (Minn. 1990), rev'd on other grounds, 501 U.S. 663 (1991) (holding that reporter's confidentiality promise did not create contract because source and reporter ordinarily do not believe they are making legally binding contract).

80 See, e.g., Hedley, supra note 76, passim; B.A. Hepple, Intention To Create Legal Relations, 28 CAmbridge L.J. 122, 134-37 (1970); Mary Keyes \& Kylie Burns, Contract and the Family: Whither Intention?, 26 Melb. U. L. Rev. 577 (2002). 
promise hereafter made and signed by the person releasing or promising shall not be invalid or unenforceable for lack of consideration, if the writing also contains an additional express statement, in any form of language, that the signer intends to be legally bound." 81 The rule gives parties who want legal enforcement of their gratuitous promises a new reason to express that preference, thereby creating unequivocal evidence of it. ${ }^{82}$ Because it manifestly sorts for the parties' contractual purpose, the Act satisfies my concept of a power-conferring rule-again, by conditioning legal change on the parties' manifestation of a legal intent.

The Model Written Obligations Act makes a practical difference only for promises without consideration and is the law only in Pennsylvania. ${ }^{83}$ More importantly, black-letter law in the United States expressly rejects the English rule's intent requirement. Section 21 of the Second Restatement stipulates that "[n]either real nor apparent intention that a promise be legally binding is essential to the formation of a contract." 84 This rule alone is strong evidence against power-conferring pictures of U.S. contract law. For all the reasons discussed above, legal powers are not the sorts of things that we expect-or that the law expressly allows-to be exercised inadvertently.

81 Model Written Obligations Act $\$ 1$, in Handbook of the National Conference of Commissioners on Uniform State Laws and Proceedings of the ThirtyFifth Annual Meeting 584 (1925) (emphasis added).

82 Unlike, for example, the rule for deeds, the Act does not require the speaker to engage in a specifically legal speech act, that is, an act that can be translated into "I hereby ...., where the ellipsis is replaced by a verb phrase describing the exercise of a legal power. Enforcement turns not on the performance of a legal speech act but on the right sort of evidence of legal intent.

8333 Pa. Cons. Stat. Ann. $§ 6$ (West 1997 \& Supp. 2008). Utah enacted the Act but then later repealed it. E. Allan Farnsworth, Changing Your Mind: The Law of Regretted Decisions 80-81 (1998); Joseph Siprut, Comment, The Peppercorn Reconsidered: Why a Promise To Sell Blackacre for Nominal Consideration Is Not Binding, But Should Be, 97 Nw. U. L. Rev. 1809, 1813-14 (2003).

84 Restatement (Second) of Contracts $\$ 21$ (1981); see also 1 Arthur Linton Corbin, Corbin on Contracts $§ 2.13$ (rev. ed. 1993) (describing U.S. rule on parties' intent to be legally bound); 1 E. Allan FArnsworth, FARnsworth on Contracts $§ 3.7$ (3d ed. 2004) (same); 1 Samuel Williston \& Richard A. Lord, A Treatise on the LAW OF Contracts $\S 3: 5$ (4th ed. 2007) [hereinafter WiLliston] (same).

Several U.S. jurisdictions regularly list an intent to be legally bound among the elements of a valid contract. See, e.g., Wyatt v. Wyatt, 65 P.3d 825, 828 (Alaska 2003); Duffy v. Duffy, 881 A.2d 630, 634 (D.C. 2005); R.I. Five v. Med. Assocs. of Bristol County, Inc., 668 A.2d 1250, 1253 (R.I. 1996). I have been unable to locate any cases in these jurisdictions, however, in which the question of contractual liability turned on an inquiry into the parties' intent to contract. The general rule that evidence of an intention to be legally bound is not essential to the formation of a contract is, however, subject to exceptions for certain types of agreements. See infra notes 108-10 and accompanying text. 
The Restatement rule on intent to contract is complex, and a few more words are needed to get at its precise meaning. While the first clause of section 21 says that legal liability does not require a manifest intent to be legally bound, the second allows that "a manifestation of intention that a promise shall not affect legal relations may prevent the formation of a contract." 85 This opt-out provision, however, is not enough to qualify the Restatement approach as a power-conferring rule. Just as permitting parties to contract out of liability for negligence does not change the tort into a legal power, allowing them to opt out of legal enforcement of their agreements is not enough to identify contract law as a power-conferring rule. ${ }^{86}$

What is crucial here is the treatment of cases where the parties do not have an intent one way or another because they have not considered the legal consequences of their act, are mistaken about the law, or are unsure about whether they want a contract. Where the blackletter English rule says no contract in such cases, the Restatement rule requires the opposite result. Thus the Restatement illustrations imagine the following case:

A orally promises to sell B a book in return for B's promise to pay $\$ 5$. A and B both think such promises are not binding unless in writing. Nevertheless there is a contract, unless one of them intends not to be legally bound and the other knows or has reason to know of that intention. ${ }^{87}$

Corbin, glossing the rule, suggests another example:

There seems to be no serious doubt that a mutual agreement to trade a horse for a cow would be an enforceable contract, even though it is made by two ignorant persons who never heard of a legal relation and who do not know that society offers any kind of a remedy for the enforcement of such an agreement. ${ }^{88}$

Between cases in which the parties objectively intend legal liability and cases in which they objectively intend no legal liability lie transactions in which the parties manifest no intent one way or another, be it because of ignorance, mistake, indifference, or indecision. A rule whose only function is to give persons the power to effect a legal change should include mechanisms to prevent inadvertent exercises of the power in such cases. But the Restatement rule stipulates that an inadvertent contract is no less legally binding than a purposeful one.

85 Restatement (Second) of Contracts $\$ 21$ (1981).

86 See id. $\S \S 195(2)-(3)$ (describing when agreement exempting party from liability for negligence is enforceable).

87 Id. $\S 21 \mathrm{cmt}$. b, illus. 2.

881 Arthur Linton Corbin, Corbin on Contracts $§ 34$, at 135 (1st ed. 1950). 
While I think there is much to this duty-imposing reading of section 21, there is another interpretation of it. Despite the Restatement's blanket language, most U.S. jurisdictions adopt something like the English rule for preliminary agreements, contracts with open terms, oral agreements that the parties expected to memorialize, and a few other transaction types. Legal enforcement of such agreements is conditioned on sufficient evidence of the parties' intent to be legally bound. For example:

In seeking to determine whether such a preliminary commitment should be considered binding, a court's task is, once again, to determine the intentions of the parties at the time of their entry into the understanding, as well as their manifestations to one another by which the understanding was reached. Courts must be particularly careful to avoid imposing liability where binding obligation was not intended. ${ }^{89}$

Because the agreements at issue are somewhat atypical, these rules need not represent the law's attitude toward contract enforcement in general. Nor is it clear that these intent-based tests are any more effective in practice than the English rule. ${ }^{90}$ All the same, they suggest an alternative reading of section 21 . Rather than expressing a judgment about which agreements should be enforced, the Restatement rule might reflect a recognition of how difficult it is to verify the

89 Teachers Ins. \& Annuity Ass'n of Am. v. Tribune Co., 670 F. Supp. 491, 499 (S.D.N.Y. 1987); see also U.C.C. § 2-204(3) (2004) ("Even though one or more terms are left open[,] a contract for sale does not fail for indefiniteness if the parties have intended to make a contract and there is a reasonably certain basis for giving an appropriate remedy."); Restatement (Second) of Contracts $\$ 33 \mathrm{cmt}$. a (1981) (noting that when some terms are left open or uncertain, if "the actions of the parties . . . show conclusively that they have intended to conclude a binding agreement, . . . courts endeavor, if possible, to attach a sufficiently definite meaning to the bargain"); id. § 27 (discussing oral agreements contemplating written memorial). The rule for ratifications of otherwise voidable agreements also suggests a test for contractual intent. See Sprecher v. Sprecher, 110 A.2d 509,512 (Md. 1955) (finding mere acquiescence or inaction insufficient to establish ratification); 5 Williston, supra note $84, \S 9: 17$, at 144-45 ("Ignorance of the party ratifying that his infancy gives him a legal defense is generally held to be immaterial, though there are cases to the contrary."). And the 2003 amendments to the Uniform Commercial Code would introduce contractual intent into the test for an enforceable click-through agreement. U.C.C. $\$ 2-204 \mathrm{cmt} .5$ (2004) ("When the requisite intent to enter into a contract exists, subsection (4)(b) validates contracts formed by an individual and an electronic agent.").

90 Of these rules, only that for preliminary agreements has received sustained scholarly attention. Allan Farnsworth concludes: "It would be difficult to find a less predictable area of contract law." E. Allan Farnsworth, Precontractual Liability and Preliminary Agreements: Fair Dealing and Failed Negotiations, 87 Colum. L. Rev. 217, 259-60 (1987); see also Alan Schwartz \& Robert E. Scott, Precontractual Liability and Preliminary Agreements, 120 HARv. L. REv. 661, 675-76 (2007) (concluding that rule for preliminary agreements "provides too little normative guidance"). 
parties' manifest contractual intent ${ }^{91}$ - the problem that has bedeviled application of the English rule. On this reading, section 21 is more an evidentiary rule than a statement of principle, grounded in the practical limitations of legal institutions when it comes to verifying even objective contractual intent. The verification problem and the importance of predictability in the commercial realm together recommend both a presumption that parties in normal transactions intended to contract and an extra-high bar for overcoming that presumptionnamely, an express statement, at the time of contracting, of a contrary intent. Courts inquire into the parties' contractual intent only in cases involving atypical agreements, where the presumption is less likely to be correct: preliminary agreements, contracts with open terms, and so forth.

This institutional-competence reading of the Restatement rule renders it compatible with interpretations of contract law as power conferring. But it does not provide empirical evidence for such interpretations. Power-conferring rules are characterized by validity conditions that sort for legal purpose. Given the absence of a legal speech act requirement and the practical irrelevance of the English rule, the power-conferring picture of contract law still requires an account of what those conditions of validity are.

This brings us to a fourth and final category of validity conditions: more amphibolous proxies for legal purpose. Power-conferring theories of contract often point here to the doctrine of consideration-the requirement that the promises and performances be "bargained for" or sought in exchange for one another. ${ }^{92}$ The thought is that parties to agreements for consideration are more likely to want legal liability than gratuitous promisors. Thus Randy Barnett argues that consideration is a good proxy for contractual intent because "the existence of a bargain so frequently corresponds to the existence of a manifested intention to be legally bound." 93 Alternatively, or in addition, exchange might serve to put the parties on notice that legal liability is

91 The Restatement rule can be traced back to section 21 of Williston's treatise. Williston suggests a number of arguments for the rule, including that where courts impose such a requirement, "the intent is frequently fictitiously assumed." 1 SAMUEL WiLliston, The Law of Contracts $\S 21$, at 23 (1st ed. 1920).

92 Restatement (SECOND) OF Contracts $\$ 71$ (1981); see also Fuller, supra note 1, at 799 n.2 (citing sources that explain consideration as means of ensuring promise was not made impulsively and without proper deliberation).

93 Randy E. Barnett, Some Problems with Contract as Promise, 77 Cornell L. Rev. 1022, 1029 (1992). Barnett explains the idea at greater length in an earlier work:

The fact that a person has received something of value in return for a "promise" may indeed indicate that this promise was an expression of intention to transfer rights. Moreover, in some circumstances where gratuitous transfers are unusual, the receipt of a benefit in return for a promise should 
in the offing. Consideration is, in Lon Fuller's words, a "natural formality" 94 that functions, inter alia, to induce "the circumspective frame of mind appropriate in one pledging his future" 95 and to separate out for legal enforcement just those agreements in which "a legal transaction was intended." 96 If these empirical claims are correct, they support an interpretation of the consideration requirement as a mechanism for limiting legal enforcement to agreements where the parties expect and want it.

As distinguished from the seal requirement, the use of nonconventional legal speech acts, and the English rule, however, the interpretation of consideration as a proxy for the parties' intent to be bound is not the only, or even the most obvious, reading of the rule. Fuller himself observed that consideration also distinguishes those agreements "of sufficient importance to our social and economic order to justify the expenditure of the time and energy necessary" for enforcement. ${ }^{97}$ Daniel Markovits argues that agreements for consideration involve a special type of moral relationship, to which the law should be particularly attentive. ${ }^{98}$ Melvin Eisenberg points to the inability of common law-style adjudication to handle the excusing conditions implicit in gift promises, such as ingratitude or change in the promisor's circumstances. ${ }^{99}$ Nor can we ignore the rule for peppercorns. Where a purported consideration is "a mere formality or pretense," the law treats it as nominal and insufficient to satisfy the consideration requirement. ${ }^{100}$ The peppercorn rule denies enforcement precisely when the parties most clearly wanted it.

The power-conferring reading of the consideration requirement therefore faces two challenges: The connection between considera-

serve as objective notice to the promisor that the promise has been interpreted by the other party to be legally binding.

Barnett, Consent Theory, supra note 5, at 313. This interpretation of the consideration requirement can be traced back to Lord Mansfield and is not uncommon in sources supporting the English rule. See Law Revision Comm., Statute of Frauds and the DocTRINE OF CONSIDERATION 14 (6th Interim Report, 1937) (describing influence of Mansfield's view on evolution of English doctrine of consideration).

94 Fuller, supra note 1 , at 815.

95 Id. at 800.

96 Id. at 801 (quoting 2 Rudolph von Jhering, Geist des Römischen Rechts 494 (8th ed. 1923)).

97 Id. at 799.

98 Daniel Markovits, Contract and Collaboration, 113 Yale L.J. 1417, 1481-91 (2004).

99 Melvin A. Eisenberg, The Principles of Consideration, 67 CoRnell L. Rev. 640, 659-62 (1982). Alternatively, one might argue that the consideration requirement is simply a historical accident and without justification. See, e.g., LAw Revision Comm., supra note 93, at 12-17 (describing history of consideration requirement and arguing that by 1937 , it had degenerated into mere technicality that did more harm than good).

100 Restatement (SECOND) of Contracts $\$ 79 \mathrm{cmt}$. d (1981). 
tion and contractual purpose is relatively attenuated, and one can imagine other reasons for limiting enforcement to exchanges. Nor are any of the other conditions of contractual validity obvious proxies for the parties' purpose. Unlike requirements that the actor perform a formal or informal legal speech act or manifest a legal intent, the consideration requirement and other conditions of contractual validity are not unmistakably designed to sort for a contractual purpose.

This explains why the power-duty distinction presents a special problem for contract theory. I have identified four types of validity conditions that can mark a law out as power conferring. Three are unequivocal in their function. Formal validity conditions, required legal speech acts, and tests for manifest legal intent all ensure that, in the normal case, an act results in legal change only if that is the actor's purpose. Where a law includes such rules, there is little question but that it is power conferring. The fourth category is something of a catchall: validity conditions that use other, less obvious proxies for contractual purpose. Most laws that we think of as private legal powers include validity conditions of one of the first two types. If contemporary contract law qualifies as power conferring, it is because it includes conditions of the fourth type. Because such proxies are more loosely correlated with the actor's legal purpose, they are more likely to serve other ends as well, rendering their function less certain. As a result, contract law's status as power conferring is contestable.

\section{III \\ Compound Rules}

None of this is to say that the power-conferring picture of contract law is wrong. Conceptual explanations of broad areas of lawcontract, tort, criminal law, administrative law-are more commonly confirmed not by this or that rule but by their ability to make sense of the domain as a whole. Because the conditions of contractual validity might be interpreted as sorting for contractual intent, contemporary contract law can be interpreted as a power-conferring rule. The strength of that interpretation will depend on its ability to make sense of the rest of contract law. We should therefore look to see whether the other rules of contract fit with the power-conferring picture.

I argued in Part I that where there is a legal power, the law will be structured in a way that anticipates and enables its purposive use. This Part identifies a number of contract doctrines that satisfy that description and therefore support a picture of contract as a legal power. These doctrines, however, are at best equivocal evidence for the power-conferring picture of contract law, and not only for the usual reason of interpretive or explanatory indeterminacy. They also 
support a very different picture of contract law, according to which contract law's function is both to impose duties and to create powers. I suggest calling laws of this type "compound" rules.

I want to introduce the idea of compound rules with a story about how a contract law like ours might come to be.

In the beginning, judges established contract law to address the wrong of betraying another's trust-of breaking a promise or violating an agreement. That is, contract law was a strictly dutyimposing rule, requiring persons to fulfill their agreements or pay for the harms they caused by breaching them. Those subject to these duties, however, quickly recognized that contractual liability could be a benefit as well as a burden. The benefit was especially apparent in forward-looking transactions between strangers where there was no pre-existing relationship of trust. Before contract law existed, strangers had been unwilling to engage in such transactions. Once contract law was in place, mistrustful strangers began to enter into agreements of that sort, based on the assurances the law now provided. That is, they entered into agreements expecting and wanting to be legally bound.

Judges quickly recognized that more forward-looking exchanges were a good thing, as was the gain in individual autonomy. So rather than discouraging this new instrumental use of contract law, they began to develop new rules that further enabled it. These rules allowed parties to modify the legal consequences of their agreements with liquidated damages clauses, damage caps, TINALEA provisions, integration clauses, standard terms, and the like. As it became clear that a great many parties were now purposely undertaking legal liability, judges, and even legislators, developed yet other doctrines predicated on that fact. The results were rules like the statute of frauds, contra proferentem, and penalty defaults-doctrines that worked on the assumption that many parties expected or wanted legal liability.

All this time (and here is the moral of the story) judges never forgot why they first created the law of contracts. They therefore rejected suggestions that they condition contractual validity on the parties' manifest intent to be legally bound or a legal speech act like the seal. And while it was true that some conditions of contractual validity, like the consideration requirement, were weakly correlated with a preference for legal liability, the purpose of those rules was never to sort for a contractual purpose. In the end, contract law emerged as a compound rule, one that both imposed duties and created powers.

The creation myth is (obviously, I hope) not meant as a piece of legal history. Its purpose is rather to demonstrate how an area of law might be structured in a way that both imposes duties and creates powers or, 
more to the point, how its function might include both. The key is that a law can anticipate and enable its instrumental use without conditioning an act's legal consequences on the actor's legal purpose.

I have argued that power-conferring laws share a common identifying mark: validity conditions that sort for their purposive use. Because there is no comparable single common mark of compound rules, the identification of a law as compound is a more complex task. Empirical evidence that contract law is a compound rule lies in the concept's explanatory power for contract law as a whole.

An obvious place to start is the fact that the conditions of contractual validity do not unequivocally sort for the parties' contractual purpose. I have argued that this fact distinguishes contract law from most legal powers, which typically require a legal speech act for their exercise. While absence of a required legal speech act does not preclude the interpretation of contract law as a power-conferring rulespecial speech acts are not the only means of sorting for actors' legal purposes-it does require explanation. Conventional legal forms like the modern seal provide cheap and effective means of ensuring that acts are undertaken with a legal purpose. Where compliance with the formal requirement is too burdensome, a law can permit the substitution of a nonconventional speech act with the same meaning or an explicit statement of intent to contract, as recommended by the Model Written Obligations Act. ${ }^{101}$

The fact that, for the most part, contract law requires none of these suggests that it does not care so much about the parties' contractual purpose as the power-conferring picture would suggest. That is, the natural explanation of the more relaxed conditions of contractual validity is that contract law does not only function to confer powers. It also imposes legal duties on those who enter into agreements for consideration simply because they have entered into an agreement for consideration, not because the parties want those legal duties. This is not yet to say just what those duties are-whether, for example, contract law imposes a duty to perform, a duty to perform if efficient, or a duty to compensate for the harms caused by breach. But the relatively forgiving conditions of contractual validity are prima facie evidence that we should attribute some duty-imposing function to contract law.

But even if we reject the power-conferring reading of the consideration requirement and allow that contract law functions to impose duties, it is difficult to ignore the fact that many parties expect and want their agreements to be legally enforceable, if for no other reason

101 See supra notes 81-82 and accompanying text. 
than that legal enforcement enables mutually beneficial transactions that would otherwise fail for a lack of trust. ${ }^{102}$ And many contract doctrines are structured in ways that anticipate, or even enable, such purposive uses of contract law.

The law of fraud will provide a helpful point of comparison. I have argued elsewhere that contracting parties often want fraud liability, including the availability of punitive damages, for certain types of misrepresentations they might make to one another. ${ }^{103}$ That is, we can predict that in some circumstances parties will use the law of fraud instrumentally-that they will make representations or contract to make them with the purpose of incurring liability in fraud should those representations be false. ${ }^{104}$ The law of fraud, however, is not structured in a way that supports and enables such purposive uses. In particular, the law does not give parties the ability to opt into or out of fraud liability, or to modify its scope or effect. Thus courts commonly refuse to enforce parties' attempts to contract out of fraud in the inducement, or to limit their legal exposure to it, on the principle that fraud vitiates everything it touches. ${ }^{05}$ Courts adopt something like the opposite, apparently mandatory rule for fraud in the performance,

102 For a detailed analysis of the different reasons for wanting to legally commit oneself in advance to an agreement, see Richard Craswell, Offer, Acceptance, and Efficient Reliance, 48 StAn. L. Rev. 481, 487-501 (1996). For a less technical version of the same idea, see Dori Kimel, From Promise to Contract: Toward a Liberal Theory of ConTRACT 57-65 (2003).

103 For example, at the time of formation, a promisor who intends to perform wants a credible means of sharing that (and other value-creating) information with the promisee. The law of fraud gives her such a means by backing up her representation of intent with punitive damages should it be false. IAn Ayres \& Gregory Klass, Insincere Promises: The Law of Misrepresented Intent 59-82 (2005). After formation, many contracts include duties to share information about a party's performance or breach. Because legal remedies for the breach of such duties make a practical difference only when they are extracompensatory, we can predict that many parties who agree to such clauses will expect and want liability in fraud, which provides such remedies when the required representations are false. Gregory Klass, Contracting for Cooperation in Recovery, 117 YALE L.J. 2 (2007).

104 This, of course, assumes that the other elements of fraud are satisfied.

105 Or, more traditionally, fraus omnia corrumpit. See ABRY Partners V, L.P. v. F \& W Acquisition LLC, 891 A.2d 1032, 1059, 1061, 1064 (Del. Ch. 2006) (refusing to enforce clause limiting liability for fraud); Restatement (SECONd) of Contracts $§ 196$ (1981) ("A term unreasonably exempting a party from the legal consequences of a misrepresentation is unenforceable on grounds of public policy."). Sophisticated parties who want to limit recovery for misrepresentations must instead use a "no reliance" clause, which in effect states that a necessary element of a fraud claim - the reliance of the injured party on the purported misrepresentation-has not been satisfied. Courts reason that where such a clause exists, permitting a claim of fraud would enable a different fraud, based on the plaintiff's false statement that she did not rely. ABRY Partners V, L.P., 891 A.2d at 1058; see also Kronenberg v. Katz, 872 A.2d 568, 593 (Del. Ch. 2004) (finding no liability in fraud based on no-reliance clause). Aside from their opacity (nonsophisticated parties might not understand that the true purpose is to avoid fraud liability), such clauses give the parties 
excluding fraud liability even where the parties had reason to want it when they entered into the contract. ${ }^{106}$ Nor does the law of fraud provide conventional forms that parties might use with certainty of their legal meaning. ${ }^{107}$ While there is evidence that parties sometimes attempt to use fraud liability as if it were a legal power, the law is not designed to facilitate such uses.

Contract law is very different, for it gives parties significant power to modify the scope of their contractual liability. This is most obvious in the rules governing the consequences of breach. Expectation damages are a default remedy. Courts regularly enforce agreements to liquidate damages, to cap liability, or to limit recovery of consequential or other special types of damages. ${ }^{108}$ They also enforce TINALEA clauses, allowing parties to opt out of legal liability entirely. ${ }^{109}$ Nor have formal modes of contracting disappeared entirely. While the seal is no longer a condition of contractual liability, many jurisdictions still recognize it as a substitute for considera-

only limited control over their legal exposure. They cannot, for example, cap or otherwise limit damages for misrepresentations but must opt out of them entirely.

106 See Klass, supra note 103, at 45-49 (discussing application of economic loss rule to bar liability for fraud for acts that are not considered to be independent from acts that breached contract). The rule is commonly justified on the grounds that fraud liability would interfere with the parties' chosen allocation of risk, reasoning that assumes that the law of fraud is not an appropriate tool for purposively allocating risk. Id. at 47-48 (citing sources that make allocation-of-risk argument). Courts have not indicated a method by which parties might opt into liability for fraud in the performance. That is, to date, the prohibition on liability for fraud in the performance appears to be a mandatory rule that applies regardless of the parties' wishes.

107 According to the Restatement, "[w]hether a statement is false depends on the meaning of the words in all the circumstances, including what may fairly be inferred from them. An assertion may also be inferred from conduct other than words." RESTATEMENT (SECOND) of Contracts $\S 159 \mathrm{cmt}$. a (1981); see also KeEton ET AL., supra note 32, $\S 106$, at 736 ("The significance to be assigned to such words or conduct will be determined according to the effect they would produce, under the circumstances, upon the ordinary mind."). There are good reasons not to adopt fixed legal interpretations in fraud, most notably that such rules tend to provide safe harbors for fraudsters to exploit. See Ayres \& KLAss, supra note 103, at 105 (noting that fixed rules provide safe harbors that protect fraud from legal scrutiny); Samuel W. Buell, Novel Criminal Fraud, 81 N.Y.U. L. REv. 1971, 1988-92 (2006) (drawing on legal history to argue that fraud has long had "a chameleon-like quality").

108 See, e.g., U.C.C. § 2-718 (2004) (describing rule for liquidated damages); id. § 2-719 (describing rule for damage caps and limits on consequential damages); RESTATEMENT (SECOND) OF Contracts $\$ 356$ (1981) (describing rule for liquidated damages); 24 WiLliston, supra note $84, \S 64: 17$ (describing rule for damage caps and limits on consequential damages); $i d$. $\S 65: 1$ (describing rule for liquidated damages).

109 Restatement (Second) of Contracts $\$ 21$ (1981) (“[A] manifestation of intention that a promise shall not affect legal relations may prevent the formation of a contract."). 
tion or as triggering a longer statute of limitations. ${ }^{110}$ That is, by adhering to optional legal form, parties can sometimes opt into greater contractual liability than would otherwise attach to their agreement.

Many of these interpretive rules too are subject to important limits. Liquidated damages clauses must be "reasonable in the light of the anticipated or actual loss." 111 And partial performance by one side or a finding of unconscionability can render a TINALEA clause unenforceable. ${ }^{112}$ Such mandatory floors indicate that the law does not allow parties to opt out of their duties to one another entirely and are consistent with a duty-imposing function. That said, contract law still gives parties considerably more control over the scope of their legal liability than, for example, the law of fraud does. The rules of contract enable the purposive use of contractual liability in a way that suggests a power-creating function.

Contract law also enables its purposive use with interpretive rules that give the parties greater control over the scope of their legal obligations. While the default is that "[w]ords and other conduct are interpreted in the light of all the circumstances," 113 parties can opt into more restrictive interpretive rules or employ formal language to achieve greater certainty. For example, by including an integration clause, parties can limit their obligations to those expressed in the four corners of a document and limit the evidence courts will use to interpret its language. ${ }^{114}$ The law also provides standard language with which parties can opt into or out of obligations. ${ }^{115}$ The Uniform Commercial Code, for example, stipulates that, by including the words "[t]here are no warranties which extend beyond the description on the face hereof," a seller can opt out of the implied warranty of fitness and that, by using "as is" or "with all faults," she can avoid all implied warranties. ${ }^{116}$ Common law courts achieve similar results by adopting fixed interpretations of standard contract language-interpretations that ignore the parties' individual "knowledge or understanding of the

110 See id. $\S 95(1)$ (providing that promise under seal is binding without consideration); Holmes, supra note 54, at 644-47, 656-63 (describing statutes reducing effect of seal to presumption of consideration and statutes of limitations for sealed instruments).

111 Restatement (Second) of Contracts § 356(1) (1981).

112 Id. $\S 21 \mathrm{cmt}$. b; see also Wendell H. Holmes, The Freedom Not To Contract, 60 Tul. L. REv. 751, 780-86 (1986) (describing cases in which TINALEA clauses are not enforced).

113 Restatement (Second) of Contracts $§ 202$ (1981).

114 Id. $\S \S 209-218$.

115 See Craswell, supra note 102, at 551-53 (describing how legal formalities function in contract interpretation).

116 U.C.C. $\$ \S 2-316(2)-(3)(a)$ (2004). 
standard terms of the writing" and, in some cases, are even contrary to the ordinary meaning of the words. ${ }^{117}$ Legal formalities of this type allow parties to opt into predefined contractual obligations easily, again facilitating their purposive assumption of contractual liability.

These rules are also subject to restrictions suggestive of a dutyimposing function. Thus the parol evidence rule permits extrinsic evidence to determine whether a document is integrated; to resolve the meaning of ambiguous terms; and, in some jurisdictions, even to determine whether there is an ambiguity. ${ }^{118}$ The Uniform Commercial Code's warranty-disclaimer language is operative "unless the circumstances indicate otherwise."119 And the Restatement rule for standard terms applies only "wherever reasonable." 120 Such nonformalist elements degrade the parties' ability to control the interpretation of their agreement and permit courts to take account of their obligations more broadly in determining the extent of their liability. Again, contract law gives the parties many more tools for controlling the scope of their obligations than does the law of fraud, but those tools are limited in ways that prevent the parties from departing too far from the extralegal obligations they might owe one another.

All of the doctrines I have discussed so far increase parties' control over the legal consequences of their agreements for consideration. That is, they further enable the purposive use of contract law. The design of other doctrines appears to anticipate such use, without necessarily facilitating it. Because such expectations are of a piece with a power-creating function, those doctrines provide additional evidence that contract is a legal power.

117 Restatement (Second) of Contracts § 211(2) (1981) ("Such a writing is interpreted wherever reasonable as treating alike all those similarly situated, without regard to their knowledge or understanding of the standard terms of the writing."). For a remarkable historical example of this rule at work in the insurance industry, see James Oldham, Insurance Litigation Involving the Zong and Other British Slave Ships, 1780-1807, 28 J. Legal Hist. 299, 300-03 (2007). See also generally Michelle E. Boardman, Contra Proferentem: The Allure of Ambiguous Boilerplate, 104 Мich. L. REv. 1105 (2006) (discussing how processes of drafting and judicial interpretation of boilerplate leads to use and retention of unclear language).

118 See Pac. Gas \& Elec. Co. v. G.W. Thomas Drayage \& Rigging Co., 442 P.2d 641, 645-46 (Cal. 1968) (holding that court may consider extrinsic evidence in determining whether term is ambiguous); Restatement (Second) of Contracts § 209 (1981) (describing rule for determining when agreement is integrated); $i d$. $\$ 212$ (describing rule for use of extrinsic evidence in interpreting ambiguous terms). See generally Eric A. Posner, The Parol Evidence Rule, the Plain Meaning Rule, and the Principles of Contractual Interpretation, 146 U. PA. L. REv. 533 (1998) (describing different versions of parol evidence rule).

119 U.C.C. $\$ 2-316(3)$ (a) (2004).

120 Restatement (SECOND) of Contracts $§ 211(2)(1981)$. 
Consider, for example, the statute of frauds, which requires that certain agreements be in writing to be enforceable. ${ }^{121} \mathrm{~A}$ familiar explanation of the rule is that it is structured to give parties a new reason to write their agreements down: Only by doing so can they get the advantages of legal liability. ${ }^{122}$ That explanation assumes the parties want to contract: Only if the parties want enforcement can the nonenforcement of oral agreements give them a reason to write those agreements down. That is, the explanation attributes to contract law an expectation that parties enter into contracts purposely. Another example is Richard Craswell's explanation of the rules governing duress, fraud, and other acts that interfere with consent:

One way to [deter acts that interfere with consent] is to not enforce any obligation whatsoever on behalf of any $X$ who has failed to obtain Y's proper consent. For example, if X forces $\mathrm{Y}$ to purchase her goods at gunpoint, the court can allow $\mathrm{Y}$ to rescind the contract entirely. This outcome may deter $\mathrm{X}$ from using duress because it denies $\mathrm{X}$ any profit from her dealings with $\mathrm{Y}$, unless she properly obtains Y's consent. ${ }^{123}$

The explanation assumes that $X$ wants legal liability, in the example because she will not get any profit from her dealings with $Y$ unless she has an enforceable contract. Finally, consider Ian Ayres and Robert Gertner's account of the Uniform Commercial Code rule that certain sales agreements lacking a quantity term will not be enforced. Ayres and Gertner argue that the rule operates as a penalty default: Assuming both parties want legal enforcement, the Code's zero default gives them a new reason to state a quantity, for only by doing so do they get enforcement. ${ }^{124}$

Each of these rules-the statute of frauds, the formation rules governing duress or fraud, and the Code's no-quantity rule-might be described instead as a condition of contractual validity, for noncompli-

121 See id. $\S 110$ (listing types of contracts commonly covered by statutes of frauds).

122 See, e.g., Karl N. Llewellyn, What Price Contract?-An Essay in Perspective, 40 Yale L.J. 704, 747 (1931); Morris G. Shanker, In Defense of the Sales Statute of Frauds and Parole [sic] Evidence Rule: A Fair Price of Admission to the Courts, 100 Com. L.J. 259, 273-76 (1995); L. Vold, The Application of the Statute of Frauds Under the Uniform Sales Act, 15 Minn. L. Rev. 391, 393-95 (1931).

123 Richard Craswell, Property Rules and Liability Rules in Unconscionability and Related Doctrines, 60 U. Chi. L. Rev. 1, 7 (1993).

124 Ian Ayres \& Robert Gertner, Filling Gaps in Incomplete Contracts: An Economic Theory of Default Rules, 99 YALE L.J. 87, 95-97 (1989). Ayres and Gertner argue that no enforcement is a preferred penalty generally: "When the rationale is to provide information to the courts, the non-enforcement default is likely to be efficient. Non-enforcement defaults are likely to provide least-cost deterrence because they are inexpensive to enforce and give each party incentives to contract around the rule." $I d$. at 98. Again, the argument is premised on parties expecting and wanting legal liability. 
ance with any one of them results in no contract. But they also appear to target undesirable behavior-not memorializing the agreement, failing to obtain consent, and omitting the quantity term, respectively. The more convincing explanation of the rules is not that they are meant to condition contractual liability on a contractual purpose but that each conditions the legal consequences of the agreement on the parties' good behavior in order to give them a reason to be good. This explanation attributes to the law an expectation that parties often want legal liability.

Also relevant are rules designed on the assumption that parties anticipate legal liability though they might not want it. A common account of the contra proferentem rule (ambiguous terms are interpreted against the drafter) is that it gives drafters who want selfserving terms a reason to state them clearly. ${ }^{125}$ This explanation assumes that the drafter anticipates legal enforcement-that she expects that a court might be called on to interpret the agreementbut not that she desires such enforcement. Many economic explanations of contract doctrines provide evidence of this sort, for they commonly adopt as a methodological premise that contract law succeeds when it creates efficient incentives (to perform, to invest, to reveal information, and so forth). ${ }^{126}$ Economic explanations that emphasize the parties' incentives before or during formation therefore typically assume that parties know the legal consequences of their actions. ${ }^{127}$ That is, such explanations attribute to the law an expectation that the parties enter into contracts knowingly, though not necessarily purposely.

125 Restatement (Second) of Contracts $\$ 206$ (1981); see, e.g., 2 Farnsworth, supra note 84, § 7.11, at 303; Omri Ben-Shahar, "Agreeing To Disagree”: Filling in Gaps in Deliberately Incomplete Contracts, 2004 Wis. L. Rev. 389, 391; Henry E. Smith, Modularity in Contracts: Boilerplate and Information Flow, 104 MicH. L. Rev. 1175, 1202 (2006).

126 This premise is akin to what Jody Kraus describes as the "ex ante" perspective of much economic analysis. Jody S. Kraus, Philosophy of Contract Law, in The OxFOrd Handbook of Jurisprudence and Philosophy of Law 687, 701 (Jules Coleman \& Scott Shapiro eds., 2002). While this methodological assumption is common among economic accounts of the law, it is by no means essential to them. Rather than providing incentives to behave efficiently, the law might promote efficient behavior through natural selection. By imposing additional liability on socially inefficient repeat players in competitive markets, the law can, in the long run, help weed them out, regardless of whether the players anticipate legal liability at any time during the transaction. I owe this point to conversations with Kathy Zeiler.

127 While the earliest economic analyses of contract law focused on the postformation reliance and breach decisions, theorists soon turned their attention to how the law affects incentives before and during formation. See Richard Craswell, Contract Remedies, Renegotiation, and the Theory of Efficient Breach, 61 S. CAL. L. Rev. 629 (1988) (describing incentive effects of remedial rules across various stages of transaction). 
The success of these explanations provides additional, albeit equivocal, evidence for theories that picture contract as a legal power. The evidence is equivocal because the existence of a legal power turns on expectations about legal actors' purposes, not their beliefs or knowledge. Economic accounts of torts and criminal law also commonly presume an awareness of legal consequences, though the objects of analysis are clearly duty-imposing rules. ${ }^{128}$ But the success of this explanatory strategy (which has arguably been greater for contract law than for other areas of the law) is not without evidentiary value for deciding whether contract is a legal power. A person who acts because she wants the legal consequences presumably believes her action will achieve them. The explanatory hypothesis that parties generally anticipate legal liability therefore conforms to, if it does not confirm, a legal assumption that parties enter into contracts purposely.

The discussion in this Part has not exhausted the ways in which contract law might be said to embody both duty-imposing and powercreating functions. Nor is the evidence I have discussed definitive. A theorist who adopts a power-conferring picture of contract law might take contract doctrines that enable or anticipate the purposive undertaking of contractual liability as further evidence, for example, for the power-conferring reading of the consideration doctrine. And because many of the above examples involve abductive inferences to the best explanation, they are inherently contestable. ${ }^{129}$ For example, an adherent to a duty-imposing picture of contract might explain the statute of frauds not by incentive effects but as an evidentiary principle, akin to the hearsay rule, presumptively excluding unreliable evidence. ${ }^{130}$ Similarly, she might explain the rules for duress and fraud not as means of deterring bad behavior but as signs of the importance contract law attaches to voluntary agreement. What counts as the better explanation of individual legal doctrines depends on broader considerations of simplicity, consistency, consilience, and the like that apply to the explanatory framework as a whole. This is but another way of saying that the best picture of contract law will be confirmed not by this or that rule but by its explanatory power as applied to contract law as a whole.

128 See, e.g., Richard A. Posner, Economic Analysis of Law 167-247 (6th ed. 2003) (discussing criminal and tort law).

129 See Gilbert H. Harman, The Inference to the Best Explanation, 74 PHIL. Rev. 88 (1965) (arguing that "inference to the best explanation" is basic form of nondeductive inference).

130 See, e.g., 2 FARnsworth, supra note 84, § 6.1, at 105 (“[The Statute of Fraud's] original purpose was evidentiary, providing some proof that the alleged agreement was actually made."); 9 Williston, supra note 84, $\$ 21: 1$, at 171 ("The Statute of Frauds was designed to prevent the enforcement of unfounded fraudulent claims."). 


\section{IV \\ Contract Theory}

I began the analysis with a puzzle from chapter 3 of The Concept of Law: How do we tell power-conferring rules from similarly structured antecedent conditions of complex, duty-imposing ones? ${ }^{131}$ It has turned out that the answer requires reformulating the question, for the private law has a more diversified topology than the traditional power-duty dichotomy captures. Between the poles of powerconferring rules and duty-imposing ones lies a third type: compound rules, or rules whose function is both to impose duties and to create powers. Pure duty-imposing rules are designed to give persons new reasons "to do or abstain from certain actions, whether they wish to or not." ${ }^{132}$ The sole function of a power-conferring rule is to give persons the ability to effect normative change when they wish. Compound rules are designed to do both. The common characteristic of all legal powers, by which they can be distinguished from the antecedent conditions of complex duties, is that the law includes rules that anticipate and enable its purposive use. In the case of powerconferring laws, that characteristic can be found in conditions of validity designed to ensure that persons normally satisfy the rule because they want the legal consequences. Compound laws do not include such validity conditions. But their design reflects an expectation that a significant proportion of legal actors satisfy the rule for the sake of the legal consequences, and compound laws facilitate such uses with rules that give persons greater control over those consequences.

In the course of drawing these distinctions, I have described how the rules of contract law might be read to support a picture of contract law as duty imposing, power conferring, or compound. This Part pulls these comments together and considers more systematically the implications for the theory of contract law. Part IV.A briefly reprises the argument for the compound picture and suggests that it fits most comfortably with pluralist justifications of contract law. Part IV.B describes an example of a compound theory of contract law, which I find in Raz's comments on the relationship between contract and promise.

131 See supra Part I.A.

132 HART, supra note 11 , at 81. 


\section{A. The Compound Picture and Pluralist Justifications}

If a law's only "normative function . . . is to provide individuals with facilities for realizing their wishes," 133 we can expect it to be designed to prevent persons from effecting legal change by accident. The challenge for power-conferring theories of contract is that contract law does not include conditions of validity whose obvious function is to ensure that parties normally want legal enforcement. This fact distinguishes contract law from most other private powerconferring laws. A will must include a publication and be signed and dated, a deed must include the right operative legal language, a power of attorney must be in the right form. A contract is simply an agreement for consideration. The parties need not perform any legal speech act, conventional or not. Nor do courts, even in England, commonly inquire into the parties' intent to be legally bound. Powerconferring theories must therefore interpret the consideration requirement or other conditions of contractual liability as mechanisms for separating out for legal enforcement those agreements in which the parties are more likely to intend legal liability. That reading, however, is not the only, or even the most obvious, interpretation of those rules.

It is at this point that duty-imposing pictures begin to look plausible. The fact that contract law does not clearly display the most common mark of legal powers-rules that condition an act's legal effect on the actor's legal purpose-suggests that it does not belong to that category. Rather than straining to interpret the consideration doctrine as a test for contractual intent, we should simply abandon the power-conferring picture and conclude that the purpose of contract law is to impose legal duties on persons entering into agreements for consideration. Such duties might include, for example, the obligation to perform one's promises or the obligation to compensate others for harms one has caused them. In either case, however, the law does not recognize the duty because the parties entered into the agreement wanting to be legally bound. The function of contract on this picture is not to give persons the ability to effect legal change purposely.

Adherents to the power-conferring picture must adduce further evidence for it. If we continue to restrict our inquiry to empirical considerations (bracketing arguments from principle), that evidence will be the theory's ability to explain and predict the other rules of contract law. The picture of contract as power entails that contract law anticipates and enables its purposive use. Evidence that contract law anticipates its purposive use can be found within contract doctrinessuch as the statute of frauds, contra proferentem, and the Uniform

133 RAZ, supra note 40 , at 158 . 
Commercial Code's zero-quantity default — that appear to be structured on the assumption that parties normally want or expect legal liability. Evidence that contract law is designed to enable its purposive use can be found in doctrines - such as the liquidated damages rule, the rule for TINALEA clauses, the parol evidence rule, and rules for standard terms - that are designed to give parties greater control over the legal consequences of their agreements.

Again, the defender of the duty-imposing picture might respond with alternative explanations of those rules-explanations that do not attribute to the law an expectation of its purposive use. But now it is the duty-imposing theorist who looks like she is held captive by a picture at the expense of the facts. Many parties do enter into their contracts expecting and wanting legal liability, and contract law does not discourage such instrumental uses but supports them. It takes willful myopia to ignore the fact that contract law is structured in a way that increases individuals' autonomy with respect to their legal obligations, and that this is a good thing.

Yet proponents of the power-conferring picture cannot rest their case on evidence that contract law anticipates and enables its instrumental use. The same evidence might be taken instead to support a very different picture, according to which contract law imposes a type of duty that also generates a legal power. On this picture, the conditions of contractual validity are not designed to ensure the parties' legal purpose, and contractual liability recognizes extralegal wrongs such as violating an agreement or causing reliance-based harms. At the same time, contractual duties are a type of legal obligation that many parties are likely to deliberately incur, and courts and legislators have taken account of that fact in designing the rules of contract law. The best evidence for the power-conferring picture-contract rules that assume that parties often want legal liability-equally supports this description of contract law as a compound rule.

One can take the argument even further. The fact that contract law does not include more familiar and effective mechanisms to sort for contractual purpose or to promote its instrumental use itself requires explanation. It is not difficult to imagine a contract law that employs formal conditions of validity, requires parties to perform a legal speech act, or demands that they state their intent to be bound. The contract law we have requires none of these. Moreover, the rules that allow parties to control the scope of their legal obligations are circumscribed in ways that suggest a duty-imposing function. TINALEA clauses are not always enforced, liquidated damages must be reasonable in light of anticipated damages, formal language is operative only when reasonable. These restrictions on the parties' 
ability to control the legal consequences of their agreements for consideration suggest an unwillingness to permit them to escape legal liability when they violate those agreements.

This argument for a compound picture of contract law is empirical and interpretive. Working from below, I have sought out the functional explanations that best account for the contract law we have. Much recent contract theory has engaged in a different project. Rather than analyzing the function of contract law, theorists have asked what principles best justify it. Such theorists commonly approach that question both from above and below: The best justification of contract law is the most normatively attractive principle (from above) that best fits the contract law we have (from below). ${ }^{134}$

It is not difficult to find in this literature principled arguments for one or another picture of contract law. As I mentioned in the Introduction, Fried's promise-based and Atiyah's reliance-and-restitutionbased theories both support duty-imposing pictures of contract law. ${ }^{135}$ On the one account, contract law functions to hold persons to their promises; on the other, it serves to compensate for reliance-based harms and prevent unjust enrichment. Barnett's consent theory recommends a power-conferring picture, as he argues that contractual liability is justified only when the parties consented to it at the time of formation. ${ }^{136}$ Yet another principled argument for the powerconferring picture can be found in Dori Kimel's claim that a robust version of the English rule is necessary to protect "the freedom to develop and reinforce personal relationships through exchanging promises" from the interference of legal enforcement. ${ }^{137}$

Because my analysis has adopted a more empirical approach, such justificatory theories need concern themselves with my conclusions only to the extent that they claim to be about the contract law we have, as distinguished from the contract law we should want. Fit and justification do not always point in the same direction. Where they diverge, a successful theory might recommend reforming the law in light of the principles that justify it.

134 See, e.g., Kimel, supra note 102; Stephen A. Smith, Contract Theory (2004); Peter Benson, The Unity of Contract Law, in The Theory of Contract Law: New Essays 118, 123-24 (Peter Benson ed., 2001); Bridgeman, supra note 5; Jody S. Kraus, Reconciling Autonomy and Efficiency in Contract Law: The Vertical Integration Strategy, 11 Phil. Issues 420 (2001); Markovits, supra note 98; T.M. Scanlon, Promises and Contracts, in The Theory of Contract Law, supra, at 86; Seana Valentine Shiffrin, The Divergence of Contract and Promise, 120 HARv. L. REv. 708 (2007); Weinrib, supra note 5.

135 Fried, supra note 2, at 17, 132; Atiyah, supra note 6; see also supra notes 6-7 and accompanying text.

136 See supra note 5 and accompanying text.

137 KIMEL, supra note 102, at 136-40. 
That said, the empirical plausibility of the compound picture provides an argument for pluralist justifications of the contract law we have. ${ }^{138}$ Lon Fuller, for example, distinguishes three substantive bases of contractual liability: individual autonomy-which suggests a power-creating function-as well as the protection of reliance and the prevention of unjust enrichment-which entail a duty-imposing one. ${ }^{139}$ Alternatively, Thomas Scanlon has argued that principles of compensatory justice, together with what he calls the "Principle of Loss Prevention," support reliance damages for broken promises, while expectation damages are justified only when parties intended legal liability. ${ }^{140}$ The first principles suggest a duty-imposing function for contract law, the second a power-creating one. And, as I argue in Part IV.B, Raz's comments on contract law suggest a compound picture in which contract law is justified as both supporting the practice of incurring and performing voluntary obligations and increasing individual autonomy. ${ }^{141}$

Jody Kraus has argued that the "challenge for [pluralist contract] theories, like the challenge for pluralistic normative theories in general, is to explain how their explanations and justifications can be defended in the absence of a master principle for ordering the competing values they invoke."142 If Kraus is correct, perhaps we should also look for an ordering principle for the different functions of con-

138 Not every pluralist theory claims that contract law should serve both a powerconferring and a duty-imposing function. Jody Kraus and Nathan Oman, for example, each recommend a theory of contract law that integrates autonomy and efficiency-two principles that, on their face, appear to recommend a power-conferring picture of contract. See generally Kraus, supra note 9; Kraus, supra note 134; Nathan Oman, Unity and Pluralism in Contract Law, 103 Mich. L. Rev. 1483, 1498-1506 (2005).

As I noted in the Introduction, my focus here is on general theories of contract. One can also find pluralist theories of individual rules. Kevin Davis, for example, argues for "a rule of enforceability [for disclaimers of fraud liability] which often, though not always, reconciles principles of respect for individual autonomy, morality and efficiency." Kevin Davis, Licensing Lies: Merger Clauses, the Parol Evidence Rule and Precontractual Misrepresentations, 33 VAL. U. L. REv. 485, 487 (1999). Similarly, Eyal Zamir argues that the restoration remedy "is justified by-or at least compatible with-various normative theories," including the will theory, corrective justice, distributive justice, economic efficiency, and contract as cooperation. Eyal Zamir, The Missing Interest: Restoration of the Contractual Equivalence, 93 VA. L. REv. 59, 103-36 (2007).

139 Fuller, supra note 1, at 806-13.

140 Scanlon, supra note 134, at 99-111.

141 Other pluralist theories of the normative grounds of contract law that might be compatible with the compound picture include Michael J. Trebilcock, The Limits of Freedom of Contract (1993), Peter A. Alces, Unintelligent Design in Contract, 2008 U. Ill. L. Rev. 505, and Melvin A. Eisenberg, The Theory of Contracts, in The Theory of ConTract LAw, supra note 134, at 206, 240-64.

142 Kraus, supra note 126, at 688 n.1. For a description of two sorts of ordering principles that might be applied to contract theory, see Kraus, supra note 134, at 422-27. 
tract law-a rule that will determine which prevails when they come into conflict. Or, in the absence of such a principle, perhaps we should take Kraus's worries to recommend dividing the law of contracts into different regions, each governed by a single principle. In fact, contemporary contract literature is filled with calls for such balkanization. ${ }^{143}$

The advantage of the compound picture with respect to these challenges is that it allows us to see how a single form of legal liability can serve two such very different functions. This is not to say that those functions, or the principles they serve, never come into conflict. Nor does it follow that the principles that justify each function are equally salient in every case. The compound picture of contract law does not exclude an ordering principle. But we should also be clear that Kraus's reasons for wanting such a principle, as well as many of the arguments for balkanization, have to do with theoretical values like internal consistency and predictive power. They are neither empirically driven nor based on a normative analysis of the proper function of contract. A contract law that serves two or more masters is more complex and difficult to navigate. But a nonordered pluralist theory might best describe the contract law we have and even be the contract law we want. ${ }^{144}$

\section{B. A Compound Theory of Contract Law: Raz on Contract and Promise}

Whether one or another pluralist theory is more convincing or better fits with the picture of contract as a compound rule is a question that lies well beyond the functionalist, conceptual-explanatory project of this Article. Still, I want to take a few pages to describe an

143 See, e.g., Brian H. Bix, Contract Rights and Remedies, and the Divergence Between Law and Morality, 21 RATIO JURIs 194, 195 n.2 (2008) (citing examples of scholarship that make such claim); Markovits, supra note 98, at 1464-73 (distinguishing moral obligations created by contracts with individuals from those created by contracts with corporations or other nonnatural entities); Alan Schwartz \& Robert E. Scott, Contract Theory and the Limits of Contract, 113 YALE L.J. 541, 543-45 (2003) (offering normative theory of contracts between sophisticated business actors).

144 Barbara Fried has some very helpful thoughts on the extent to which contract theory should consider itself beholden to the "hodge-podge of often inconsistent intuitions, drawn from [a variety of] normative principles" that stand behind contract law. Fried, supra note 61, at 1385-89. Melvin Eisenberg makes a similar point:

Part of the human moral condition is that we hold many proper values, some of which will conflict in given cases, and part of the human social condition is that many values are relevant to the creation of a good world, some of which will conflict in given cases. Contract law cannot escape these moral and social conditions.

Eisenberg, supra note 141, at 240-41. 
example of such a theory, which I find in Joseph Raz's observations about the relationship between contract law and voluntary obligations. This might seem an odd choice. Raz's scattered comments on contract law do not amount to a full-blown theory, and they are now three decades old. ${ }^{145}$ Those comments, however, continue to resonate in the literature. ${ }^{146}$ And while Raz himself does not identify my category of compound rules, his description of contract law provides the materials for a sophisticated compound theory of the practice.

Raz's approach to contract law builds on two pieces of his theory of normative systems. The first is his concept of voluntary obligations. In his review of Atiyah's Promises, Morals, and Law, Raz discusses the moral and other nonlegal obligations we owe those with whom we enter into significant relationships (partners, friends, children, promisees, and the like). ${ }^{147}$ He labels relationship-based obligations "voluntary" when three conditions are met: entering into the relationship is a voluntary act (the obligation can be avoided), the agent is aware of the relationship's normative implications, and "the agent's belief that he will incur an obligation by his action is a positive reason for holding him bound by his action."148

The third characteristic of voluntary obligations is similar to Raz's account of a normative power: "An act is the exercise of a

145 The most pertinent texts are Joseph Raz, Promises and Obligations, in Law, Morality, And Society: Essays in Honour of H.L.A. Hart 210 (P.M.S. Hacker \& J. Raz eds., 1977) [hereinafter Raz, Promises and Obligations], Joseph Raz, Promises in Morality and Law, 95 Harv. L. Rev. 916 (1982) [hereinafter Raz, Promises in Morality and Law] (reviewing P.S. Atiyah, Promises, Morals, And Law (1981)), and Raz's Voluntary Obligations and Normative Powers, supra note 15.

146 See, e.g., KIMEL, supra note 102, at 27-29, 90; Markovits, supra note 98, at 1440-41, 1511-12; Pratt, Promises, Contracts and Voluntary Obligations, supra note 5; Hanoch Sheinman, Contractual Liability and Voluntary Undertakings, 20 OxFord J. LEgAL STUd. 205, 208 \& n.7, 211 \& n.11 (2000); Smith, supra note 7, at 367-69 (1997).

147 Raz, Promises in Morality and Law, supra note 145, at 929.

148 Id. at 929, 930. It is worth noting Raz's observation that many of these obligations do not rest on a promise: "[N]ot all voluntary obligations are promises. But whatever reason there is for the law to protect the promising practice requires it to protect the wider practice of undertaking voluntary obligations of any kind." Id. at 936. My analysis of the concept of voluntary obligations is similar to Penner's analysis in J.E. Penner, Voluntary Obligations and the Scope of the Law of Contract, 2 LEgAL THEORY 325, 326-40 (1996). Penner's article deserves more attention from contract theorists than it has so far received and more extended discussion than I will give it here. While I am sympathetic to Penner's distinction between promises and agreements, which characterizes promises as unilateral and agreements as bilateral, id. at 328-30, I would add that not all agreements, or the associated voluntary obligations, result from the exercise of normative powers. Michael Bratman makes the point about agreements without promises in MiCHAEL E. Bratman, Shared Intention, in FACES of InTENTION: SElected Essays on InTENTION ANd Agency 109, 125-29 (1999). Whether or when the shared projects Bratman describes also involve voluntary obligations-not as preconditions but as ordinary consequences-is a question that, to my knowledge, the philosophical literature has yet to address. 
power only if the reason for recognizing it as affecting norms and their application is that it is desirable to enable people to affect norms and their application in such a way if they desire to do so for this purpose."149 But, where the exercise of a normative power turns on agents' presumed purpose ("if they desire to do so"), a voluntary relationship-based obligation depends on an agent's awareness of the normative consequences of entering into the relationship ("the agent's belief that he will incur an obligation"). While Raz does not comment on the difference, it can be explained by the fact that we enter into normatively significant relationships with one another for a variety of reasons, and it is often impossible to disentangle or distinguish a purely normative motive or purpose among them. When we offer our services to others, engage in cooperative activities with them, or agree to take on a role in a relationship, the resulting voluntary obligations are not conditioned on, or explained by, our desire to be obligated but only on our belief that we will be. That is, we often incur voluntary obligations without exercising a normative power per se. ${ }^{150}$

While not every voluntary obligation results from the exercise of a normative power, to exercise a normative power to undertake an obligation to another is to undertake a voluntary obligation. Consider making a morally binding promise. "To promise is . . . to communicate an intention to undertake by the very act of communication an obligation to perform a certain action." 151 The promisor's purpose explains her act of promising only if she also believes that her communication of intent will result in a promissory obligation. That is, the purposive actions that underwrite the exercise of a normative power to obligate oneself to another entail the sorts of practical beliefs that characterize voluntary obligations. Consequently, the exercise of a normative power to undertake a duty, when it works, results in a voluntary obligation (though, again, not all voluntary obligations result from the exercise of a normative power).

\footnotetext{
149 RAz, supra note 31 , at 102.

150 My reading of Raz on voluntary obligations differs from Hanoch Sheinman's. For Sheinman, a voluntary obligation arises when there is an "intention not simply to do the act, but to do it in order to incur an obligation," and "the act of a voluntary undertaking is not complete unless it includes a successful representation of the same intention." Sheinman, supra note 146, at 211. Where Sheinman sees purpose, I see mere knowledge as sufficient.

151 Raz, Promises and Obligations, supra note 145, at 218. Raz expresses the same point in slightly different language: "[T]he only belief that the promisor need always intend to induce or be taken to have the intention of inducing is the belief that he (the promisor) intends to undertake an obligation and to confer a right on the promisee." Raz, supra note 15, at 100. For arguments that promising is not a normative power in Raz's narrow sense, see Markovits, supra note 98, at 1442-46, and Pratt, Promises, Contracts and Voluntary Obligations, supra note 5.
} 
The second relevant piece of Raz's general theory is his thesis that law is an open system. A normative system is open if it "contains norms the purpose of which is to give binding force within the system to norms which do not belong to it." 152 The idea of an open system is important for understanding Raz on contract because he maintains that one function of contract law is to protect and support the social practice of undertaking and performing voluntary obligations. Contractual duties therefore correspond to extralegal voluntary obligations. Or, as Raz puts the point, "[c]ontracts are not laws; they are merely legally recognized norms." 153

Complicating matters further, Raz also distinguishes between two ways in which one normative system can give binding force, or "recognize," the norms of another. ${ }^{154}$ Normative system $S_{1}$ derivatively recognizes the norms of system $S_{2}$ when its reason for enforcing them is "to respect and enforce" the practices of $S_{2}$, that is, when the validity of the norm in $S_{2}$ is a sufficient reason for recognizing it in $S_{1} .{ }^{155} \mathrm{Raz}$ 's example of derivative recognition is the application of a foreign law. Once a court has decided that the law of another jurisdiction governs, the only question left is what the law in that jurisdiction is, not whether it is justified or its application desirable. ${ }^{156}$ Contract theories that explain contractual obligations solely in terms of a preexisting moral obligation (whether to perform or to compensate or to restore) describe the law as derivatively recognizing those obligations. According to these theories, contract law is a duty-imposing rule that gives such obligations binding force "only because they are recognized according to sound moral principles." 157

Raz terms other forms of recognition original. His account of the distinction suggests that the categories of derivative and original recognition are exhaustive. That is, any recognition that is not derivative is original. If this is right, $S_{1}$ originally recognizes a norm of $S_{2}$ whenever its reason for recognizing that norm is not only that it is a norm of $S_{2}$. That is, $S_{1}$ originally recognizes a norm of $S_{2}$ only if the fact that

\footnotetext{
152 Joseph Raz, The Institutional Nature of Law, in The Authority of Law, supra note 21 , at 119 .

153 Raz, supra note 15 , at 87.

154 For various versions of this distinction, see RAz, supra note 152, at 120, RAZ, supra note 31 , at $153-54$, and Raz, supra note 15 , at $86-87$.

155 Raz, supra note 15 , at 86.

156 This statement must be qualified by the fact that a court may refuse to apply a foreign law contrary to the public policy of the forum. See, e.g., Kilberg v. Ne. Airlines, Inc., 172 N.E.2d 526, 528 (N.Y. 1961) (holding that public policy of New York prevented application of damage limitation in Massachusetts death statute). It does not follow from the fact that a policy of the forum can defeat application of the foreign law that conformity with the policies of the forum is the reason for applying that law.

157 Raz, supra note 15 , at 87.
} 
the norm belongs to $S_{2}$ is not a sufficient reason for giving it binding force in $S_{1} .{ }^{158}$ This is how Raz describes the relationship between contract law and the voluntary obligations it supports:

Though the fact that many contracts are morally binding, and more important still the fact that they are socially accepted as binding, are part of the reasons for their legal recognition, ultimately they are recognized in law because, regardless of moral and social norms, they are considered as a desirable means to achieve some legitimate ends. ${ }^{159}$

Contract law gives legal force to voluntary moral obligations, but not only because of their moral force.

To say that contract law originally recognizes extralegal voluntary obligations is not yet to say whether contract law imposes duties or confers powers. This turns on the law's reason for recognizing these voluntary obligations. If its reason for recognizing them is that those social practices are valuable and legal recognition lends them support, then the function of contract law is to impose duties. ${ }^{160}$ If, on the contrary, the reason for recognizing these norms is to allow persons to change their normative status purposively, the function is to confer powers.

That said, there is a close connection between original recognition of any type and the creation of new normative powers. Legal

158 Raz's definition of "original recognition" is somewhat different from the above description and places greater emphasis on the connection to normative powers:

But some powers not directly affecting the laws of $S_{1}$ may be recognized in $S_{1}$ for different reasons. The law may simply intend to create ways in which individuals may achieve certain results even though these ways are not recognized by some other norms. The powers to make and amend the regulations of private companies are an example of this kind of recognition. They are normative powers because they affect the company's regulations, which are norms. They are recognized in law since they indirectly affect the duties of the courts to enforce these regulations. But a company's regulations are not part of the legal system, nor are they recognized in law because they are conventional social rules. These powers are powers directly affecting norms which are not laws of the system but they are given original rather than derivative recognition.

Raz, supra note 15, at 86; see also RAz, supra note 152, at 120 (providing similar definition of original recognition). On this definition, it can look as if $S_{1}$ originally recognizes a norm of $S_{2}$ only if, by giving binding force to certain acts, $S_{1}$ also creates a normative power operating in $S_{2}$ (as the law of corporations gives a corporate board the power to alter the rules of the corporation), and perhaps also only if creating that power is $S_{1}$ 's reason for recognizing the norms of $S_{2}$ ("[ $\left.\mathrm{t}\right]$ he law may simply intend to create ways in which individuals may achieve certain results"). I argue below that while there are conceptual connections between original recognition and the creation of powers, it is not so tight as this description suggests.

159 Raz, supra note 15 , at 87.

160 The same would be so if, for example, the law's reason for recognizing a norm derived from a political principle of corrective justice. 
recognition of an extralegal norm can affect that norm. ${ }^{161}$ Among other things, legal recognition can enable new applications of it. Consider the law of corporations. While a corporation's rules are not laws, their legal recognition enables forms of corporate organization that would otherwise be impossible. ${ }^{162}$ Persons who purposely effect normative changes in $S_{2}$ that are possible only because those norms will be recognized in $S_{1}$ are doing something like exercising a normative power. Their purpose refers both to the norms of $S_{2}$, in which the change operates, and to the norms of $S_{1}$, which makes those changes possible. If the reason the law gives binding force to extralegal norms is merely "to respect and enforce" them (derivative recognition), it might well be averse to such normative innovation. If the law gives those norms force for other, legal reasons (original recognition), it is more likely to permit such innovation-even if its reasons for recognition entail a duty-imposing function. And where the law not only permits but also encourages that innovation, there also exists a legal power.

Raz's description of contract law exemplifies this interplay between original recognition and the creation of normative powers:

[W] hen the role of the law is entirely supportive (which is not true of contract law), then the law should faithfully follow social practices and individuals need have no inkling of the law in advance of a dispute. They can rely entirely on their knowledge of the social practice.

It would be wrong, however, to assume that, where the law's role is predominantly supportive, it has a merely passive function and does not influence the social practices it supports. . . . In addition to reinforcing existing practices, the law serves to extend such practices. But for the support of the law, contracts between complete strangers would not be as numerous and common as they are. ${ }^{163}$

I suggest we read this as follows. One of the purposes of contract law is to support the norms governing certain voluntary obligations, for the reason that both undertaking and performing those obligations are socially valuable. This is a form of original recognition: Contract law enforces voluntary obligations, but not only because of their morally

\footnotetext{
161 The point is a more general one than the sorts of effects I consider here. An obvious example is the effect on religious practice of the state's recognition of that religion. As Steve Goldberg points out, for example, the time given the chanukiah (the nine-branched Chanukah menorah) on the public square has helped elevate it above other, more traditional symbols of Judaism. Steven Goldberg, Bleached Faith: The Tragic Cost When Religion Is Forced into the Public Souare 66-93 (2008).

162 See supra note 158.

163 Raz, Promises in Morality and Law, supra note 145, at 934 (emphases added).
} 
obligatory character. ${ }^{164}$ If this were the only reason for legal enforcement, contract law would have a strictly duty-imposing function: Contract law would support the practice of undertaking voluntary obligations by enforcing those obligations, not by giving persons the ability to purposively undertake new ones. But this is not contract law's only function. In addition to supporting voluntary obligations, it also "serves to extend such practices"-that is, to permit and encourage normative innovation, such as transactions between strangers where there is no pre-existing relationship of trust (not to mention innovations that come with choice-of-law clauses, liquidated damages, warranty disclaimers, and the like). Because individual actors who effect normative change in the extension expect and want the legal consequences that make such normative change possible, and because contract law anticipates and enables such uses, contract is also a legal power.

While I am sympathetic to this general approach, I do not think Raz hits the nail on the head when he writes that this feature of legal powers "explains why they are exercised either by special formal and ceremonial acts as in making a deed or getting married, or by ordinary actions whose legal consequences approximate to their non-legal and obvious consequences, as in making a contract." 165 The latter claim is presumably based on the empirical observation that if contract is a legal power, it is not exercised by way of legal speech acts. While the observation is correct, Raz's explanation of how entering into a contract functions as a legal power-because the legal consequences of entering into an agreement for consideration approximate the nonlegal ones-obscures more than it illuminates. Identifying the problems with the claim will clarify what is right in Raz's overall approach to contract.

First, assuming that the content of contractual obligations does approximate that of extralegal voluntary obligations, it is unclear how that fact links up with Raz's functionalist definition of legal powers. The definition holds that an act counts as the exercise of a legal power only if "actions of that type will, if they are recognized to have certain legal consequences, standardly be performed only if the person concerned wants to secure those legal consequences."166 There is no reason to think that "ordinary actions whose legal consequences

164 "It may be that the facts which contribute to the argument for regarding promises as morally binding are also among the facts which make it desirable to make contracts binding in law. But it is these facts which count and not their results in morality." Raz, supra note 15 , at 87.

$165 \mathrm{Id}$. at 81 (emphasis added).

166 Id. (emphasis added). 
approximate to their nonlegal and obvious consequences" satisfy that condition. For one thing, there are often significant differences between the legal and nonlegal consequences of violating the obligation. No matter how closely contractual duties map onto the norms governing agreements for consideration, the legal remedies for breach of contract are distinct from, and often more severe than, the informal sanctions for violating an agreement. ${ }^{167}$ And remedial differences aside, it simply does not follow from the fact that a person is willing to undertake a moral obligation that she also wants to be legally obliged to comply with it. ${ }^{168}$

If this is somewhat abstract, consider the moral obligation to tell the truth, which is recognized in the law of deceit. ${ }^{169}$ I take it as uncontroversial that communicative acts bring with them an obligation to tell the truth. Somewhat less obvious, but hardly beyond the pale, is the claim that there is also a voluntary obligation to be truthful: Through their awareness of the mutual obligation not to mislead, interlocutors enter into a morally significant relationship of trust and respect, a relationship that generates its own obligations. ${ }^{170}$ The law of deceit imposes legal obligations that largely track those voluntary obligations for statements to which it applies. A speaker's legal obligation to tell the truth approximates her ordinary and obvious extralegal voluntary obligation to do so. Yet it would be odd to say that she has thereby exercised the legal power to undertake liability in deceit. It is odd because we typically have no reason to expect that

167 Dori Kimel takes this fact as grounds for arguing that an intent to exercise the moral power might well be a reason for preferring that legal liability not attach. Kimel maintains that the threat of legal enforcement casts a veil over the promisor's motives, interfering with the intrinsic value of promise-keeping in building and maintaining relationships of trust. Kimel, supra note 102, at 74.

As David Owens has pointed out to me, Raz does not think legal obligations must come with sanctions. That is, a contractual obligation might exist without any sanction attached to breach. But that is not the contract law we have. While different remedial consequences might not be a necessary feature of the legal recognition of voluntary obligations, it is a possible one. This is enough to block the general inference from an intent to undertake a voluntary obligation to an intent to undertake a corresponding legal one. Nor, as I argue above, are remedial consequences the only difference between a legal and extralegal obligation.

168 The above argument is the mirror image of Michael Pratt's suggestion that undertaking a contractual obligation does not necessarily entail undertaking a corresponding promissory one. Pratt, Contract: Not Promise, supra note 5, at 1-2, 8-9. While I agree with Pratt's argument with respect to promissory obligations, I would take issue with his premise that "[i]n order to form a contract[,] at least one of the parties to the bargain ... must perform a commissive speech act of the right kind." Id. at 1.

169 I am using "deceit" here to refer to both fraud and negligent misrepresentation.

170 See Markovits, supra note 98, at 1422-28 (describing Kantian idea that wrongness of lying inheres in liar's treatment of his listener as means to liar's ends). 
she anticipates or wants legal liability, even if she expects or wants the moral obligation. ${ }^{171}$ Approximation does not show purpose.

Second, it is far from obvious that Raz's approximation thesisthat the legal consequences of entering into an agreement for consideration approximate the extralegal ones-is correct. Seana Shiffrin has argued that the rules limiting the availability of specific performance, those involving mitigation, and those prohibiting penalties and punitive damages together mean that "the contents of the legal obligations and the legal significance of their breach do not correspond to the moral obligations and the moral significance of their breach." 172 In addition to the remedial rules Shiffrin emphasizes, interpretive doctrines like the statute of frauds and the parol evidence rule in many cases result in legal duties whose content differs significantly from the extralegal voluntary obligations that attach to the agreement. Nonmajoritarian or untailored interpretive defaults are also likely to produce a gap between the parties' legal duties and their untutored expectations about their obligations to one another, as are other rules championed by the "new formalism" in contract law. ${ }^{173}$

Third, these differences are consistent with the more general fact that approximation between legal and extralegal obligations is not a necessary condition of contract law's power-creating function. ${ }^{174}$ Many of the rules that increase contracting parties' control over their legal obligations are the same ones that create the gap between legal and extralegal obligations to one another. To mention three examples: TINALEA clauses can permit parties to opt out of legal liability for breach, though they still have a moral obligation to perform; a sealed gratuitous promise might create legal obligations where moral considerations (for instance, the promisee's subsequent ingratitude) would excuse the promisor from performance; and an integration

171 And as I argued in Part III, even where we have a reason to expect speakers to want to be held legally liable for their misrepresentations, the law of fraud is not structured in a way that manifests a legal expectation of the same. See supra notes 102-07 and accompanying text.

172 Shiffrin, supra note 134 , at 709.

173 See David Charny, The New Formalism in Contract, 66 U. CHI. L. Rev. 842 (1999) (discussing return to formalism among many contracts scholars); Schwartz \& Scott, supra note 143 (advocating formalist law of contracts for business transactions). These divergences go beyond the points of departure Raz predicts based either on lawmakers' attempts at moral innovation or on the need to prevent people from taking advantage of the underlying moral practice. Raz, Promises in Morality and Law, supra note 145, at 935-36.

174 Approximation might be a necessary condition of the other function Raz ascribes to contract: supporting the extralegal practice of undertaking and performing voluntary obligations. If contract law supports that practice, it would seem to be by making extralegal wrongs also legal ones. 
clause can cause a contract's legal meaning to differ from the parties' actual agreement. Contract law serves a power-creating function not because the parties' contractual duties approximate their extralegal ones, but because many parties want legal enforcement of their agreements and contract law is structured in a way that anticipates and facilitates their attempts to get it.

Finally, and most importantly, Raz's approximation thesis invites a false understanding of the interplay between contracting, promising, and the existence of normative powers. It is not uncommon to describe the undertakings of the voluntary obligations that underlie contractual obligations as promises. ${ }^{175}$ If one also thinks of promises as normative powers, it is then a short step to the conclusion that a general awareness of the legal consequences of one's promise is enough to transform the moral normative power into a legal one. On this view, the approximation of a promise's legal and extralegal consequences is important because it increases the likelihood that the promisor will anticipate the legal consequences of her act, transforming her exercise of a moral power into the exercise of a legal one.

I think that something like the above line of reasoning underlies many theorists' intuitions that contract is a normative power. But it is wrong on at least two counts. First, the voluntary obligations that contract law supports are not limited to promissory ones and need not result from the exercise of a normative power per se. This is the significance of the fact, noted in Part II, that the law does not require parties to express their agreements in so many words. ${ }^{176}$ Second, even if those obligations were based on exercises of the moral power of promising, it would not follow that contract is a legal power. A normative power qualifies as a legal power only if the law expects and enables persons to exercise the power with the purpose of achieving the legal consequences. An extralegal normative power that has legal consequences is not, as such, a legal power-even if the legal consequences of its exercise approximate the extralegal ones.

Raz's approximation thesis does not fit with his own theory of normative powers, his other comments on contract law, or the compound theory that they suggest. My extended discussion of it is not intended as a criticism-one might read the approximation thesis instead as an oblique reference to the complex theory of contract as original recognition that Raz develops in the same article and elsewhere. I hope, rather, that it illuminates what is right about Raz's

175 E.g., Fried, supra note 2, at 7-27; Markovits, supra note 98, at 1448, 1463; Shiffrin, supra note 134 , at $749-53$.

176 See supra notes $61-67$ and accompanying text. 
picture of contract law as both duty imposing and power creating. The legal principles that recommend supporting the practice of undertaking and performing voluntary obligations suggest a duty-imposing function for contract law; the principles that recommend facilitating the extension of that practice in new directions suggest a powerconferring function. Contract law is unusual because it is structured to do both at once.

\section{CONCLUSION}

The analysis in the last section is not meant to endorse everything Raz has to say about contract law. I have doubts about the intelligibility of his claim that the law holds parties to their agreements in part to support or protect the social practice of undertaking and performing voluntary obligations. ${ }^{177}$ But the goal of this Article has not been to produce a general theory of contract law. Rather, the aim has been to distinguish two common pictures of contract law's function, to analyze the empirical basis of each, and to suggest a third, underappreciated possibility. The two common pictures are contract as power and contract as duty. The third depicts contract law as a compound rule, both duty and power.

Regardless of whether the above analysis definitively establishes the correctness of one or another picture (I am obviously attached to the compound picture), it at least explains why the duty-power distinction deserves a place at the center of contract theory. First, the legal relationship coincides with a constellation of similarly structured extralegal practices-such as agreement, exchange, cooperation, and promise-which suggests the duty-imposing picture. Second, with the decline of the seal, contracts are not marked out by formal or other conditions of validity that unequivocally sort for a legal purpose, rules that would clearly identify contract law as power conferring. Third, while it is uncertain whether contract law sorts for a contractual purpose, there is no doubt that many parties expect and want contractual liability and that the law is designed to facilitate such uses-characteristics that distinguish contract law from other, purely duty-imposing rules. Together these distinctive features render both pure powerconferring and pure duty-imposing theories of contract law inherently contestable. They also provide support for the idea that contract law partakes in characteristics of both, such that it is best described as a compound rule.

177 If one wants to look for legal doctrines that protect against the abuse of those norms, the law of promissory fraud and the tort of bad faith breach are much better candidates than the law of contract. For a defense of Raz's claim, see Sheinman, supra note 146, at 216-19. 